\title{
Complex examination of the Upper Paleozoic siliciclastic rocks from southern Transdanubia, SW Hungary-Mineralogical, petrographic, and geochemical study
}

\author{
Andrea Varga ${ }^{\dagger}$ \\ György Szakmány \\ Tibor Árgyelán \\ Sándor Józsa \\ Department of Petrology and Geochemistry, Eötvös University, Pázmány Péter sétány 1/C, H-1117 Budapest, Hungary \\ Béla Raucsik $\$$ \\ Department of Earth and Environmental Sciences, University of Veszprém, P.O. Box 158, H-8201 Veszprém, Hungary \\ Zoltán Máthé ${ }^{\#}$ \\ Mecsek Ore Environment, P.O. Box 121, H-7614 Pécs, Hungary
}

\begin{abstract}
A vertical section of Upper Paleozoic sandstones from southern Transdanubia (Mecsek-Villány area, Tisza mega-unit, Hungary) has been analyzed for major and trace elements, including rare earth elements (REEs). In addition, the clay mineralogy of the sandstone samples and the petrography and geochemistry of gneiss and granitoid clasts extracted from the associated conglomerates have been determined.

Geochemistry of the sandstone samples analyzed in this study shows that these rocks were predominantly derived from a felsic continental source; nevertheless, compositions vary systematically up-section. The Pennsylvanian (Upper Carboniferous) Téseny Formation has higher $\mathrm{SiO}_{2}$ and lower $\mathrm{Na}_{2} \mathrm{O}, \mathrm{CaO}$, $\mathrm{Sr}$, high field strength element (HFSE), and $\Sigma$ REE contents relative to the Permian strata. Its high $\mathrm{K}_{2} \mathrm{O}$ and $\mathrm{Rb}$ contents together with the presence of abundant illite-sericite suggest a potassium metasomatism in this formation. Clay mineralogy and large ion lithophile element (LILE) contents of the Lower Permian Korpád Formation vary spatially and are interpreted as local variations in composition of the source region and postdepositional conditions. $\mathrm{Zr}$ and $\mathrm{Hf}$ abundances and REE patterns, however, show that this formation was derived from mature upper continental crust. The Upper Permian Cserdi
\end{abstract}

\footnotetext{
${ }^{\dagger} \mathrm{E}$-mail: raucsikvarga@freemail.hu.

"E-mail: gyorgy.szakmany@geology.elte.hu.

§E-mail: raucsik@almos.vein.hu.

"E-mail: mathezoltan@mecsekerc.hu.
}

Varga, A., Szakmány, G., Árgyelán, T., Józsa, S., Raucsik, B., and Máthé, Z., 2007, Complex examination of the Upper Paleozoic siliciclastic rocks from southern Transdanubia, SW Hungary-Mineralogical, petrographic, and geochemical study, in Arribas, J., Critelli, S., and Johnsson, M.J., eds., Sedimentary Provenance and Petrogenesis: Perspectives from Petrography and Geochemistry: Geological Society of America Special Paper 420, p. XXX-XXX, doi: 10.1130/2006.2420(14). For permission to copy, contact editing@geosociety.org. (C2007 Geological Society of America. All rights reserved. 
Varga et al.

Formation has higher $\mathrm{TiO}_{2}$, Th, U, Y, Cr, and heavy (H) REE contents, and higher $\mathrm{Cr} / \mathrm{Th}$ and $\mathrm{Cr} / \mathrm{Zr}$ ratios relative to the underlying formations. These trends can be explained by a sedimentary system dominated by highly weathered detritus derived from combined recycled-orogen, basement-uplift, and volcanic-arc provenance in the Téseny Formation, with an increased proportion of less weathered detritus derived from combined volcanic and basement-uplift provenances in the Permian formations. Characteristics of the Cserdi unit may reflect relatively proximal derivation from a felsic volcanic source.

Keywords: late Paleozoic, clay mineralogy, geochemistry, provenance, European plate, Hungary.

\section{INTRODUCTION}

Sandstone geochemistry is widely considered to be a powerful tool for determining the sediment source areas and tectonic settings of ancient terrigenous deposits (Bhatia, 1985; Bhatia and Crook, 1986; Bauluz et al., 1995; Garver and Scott, 1995; Cullers and Berendsen, 1998; Zimmermann and Bahlburg, 2003). Whole-rock chemistry can also detect variations in elements that are not picked up in modal analysis, for example, rare earths elements (REE), Th, $\mathrm{Zr}, \mathrm{Sc}$, and Cr (Willan, 2003). In addition, variations in clay-mineral assemblages also may be useful for detecting changes in the source areas and for recognizing the diagenetic conditions of sandstone units (Weaver, 1989; Bauluz et al., 1995; Arribas et al., 2003). On the other hand, relatively few papers deal specifically with clast composition of coexisting conglomerates in the same locality (Floyd et al., 1991; Brügel et al., 2003; Varga et al., 2003; Noda et al., 2004); however, the clast types can provide a wealth of information concerning the provenance and geological evolution of the sediment source areas. Therefore, integrated examination of siliciclastic rocks, including clay mineralogy, whole-rock geochemistry, and clast petrography and geochemistry, is particularly fruitful in provenance analysis and paleogeographic reconstruction.

In this paper, results of clay mineralogical, petrographic, and geochemical studies of the late Paleozoic siliciclastic successions from southern Transdanubia (Mecsek-Villány area, Tisza mega-unit, SW Hungary) are presented.

Previous research on Paleozoic siliciclastic rocks in southern Transdanubia has been restricted to conventional sedimentological and petrographic analyses (Jámbor, 1969; Balogh and Barabás, 1972; Hetényi and Ravasz-Baranyai, 1976; Fazekas, 1987; Barabás and Barabás-Stuhl, 1998). Recently, Varga et al. (2001, 2003, 2004) and Varga and Szakmány (2004) reported the provenance and chemical composition of the Pennsylvanian sedimentary rocks. They showed that these sediments are predominantly composed of material from a recycled orogenic area with small amounts of volcanic-derived detritus. On the other hand, no major and trace element data for sandstones of the Permian formations are available at present. For this reason, this study was aimed at providing a contribution to a database on the elemental concentrations of the Upper Paleozoic sandstones in this region.

We concentrated this study on clay mineralogical, petrological, and geochemical analyses of sandstone and conglomerate samples. Examination of detritus in Pennsylvanian to Permian sediments in the Mecsek-Villány area is useful for gathering information about the provenance and reconstructing the paleogeographic setting of the late Paleozoic southern margin of the European plate.

\section{GEOLOGIC AND PALEOGEOGRAPHIC SETTING}

Hungary is located in the central Carpathian-Pannonian area (Fig. 1). The Mid-Hungarian line, a key element in the tectonics of the intra-Carpathian area, subdivides its pre-Tertiary basement in two parts: the Alcapa (Alpine-west Carpathian-Pannonian) block on the north and the Tisza mega-unit (Tisza-Dacia unit) on the south (Csontos and Nagymarosy, 1998; Csontos et al., 1992, 2002). Paleogeographically, at the end of the Variscan cycle, the polymetamorphic complexes of the Tisza mega-unit belonged to the southern part of the Moldanubian zone (Variscan orogenic belt), which formed the European margin of Paleotethys (Haas et al., 1999; Buda et al., 2000). During the late Paleozoic interval, the position of the Tisza mega-unit has been determined to be at the southern margin of the European plate, east of the Bohemian Massif and the western Carpathians (Fig. 2). Within it, the Mecsek-Villány area was probably located in the most external position (Haas et al., 1999).

Following the Variscan orogeny, the Tisza mega-unit was affected by an extensional tectonic regime. Variscan postorogenic sedimentation began earlier in the Villány area than in the Mecsek area and produced a Pennsylvanian nonmetamorphic (locally anchimetamorphic) molasse-type overstep sequence (Téseny Sandstone Formation), which was draped over the eroded surface of the crystalline basement (Hetényi and RavaszBaranyai, 1976; Fülöp, 1994; Barabás and Barabás-Stuhl, 1998; Szederkényi, 2001). This formation was deposited in a foreland basin (Jámbor, 1969; Hetényi and Ravasz-Baranyai, 1976; Varga et al., 2003). In the Early Permian, continental sedimentation continued in the previously formed molasse basins and initiated in the newly formed extensional rift troughs (Turony Formation, 

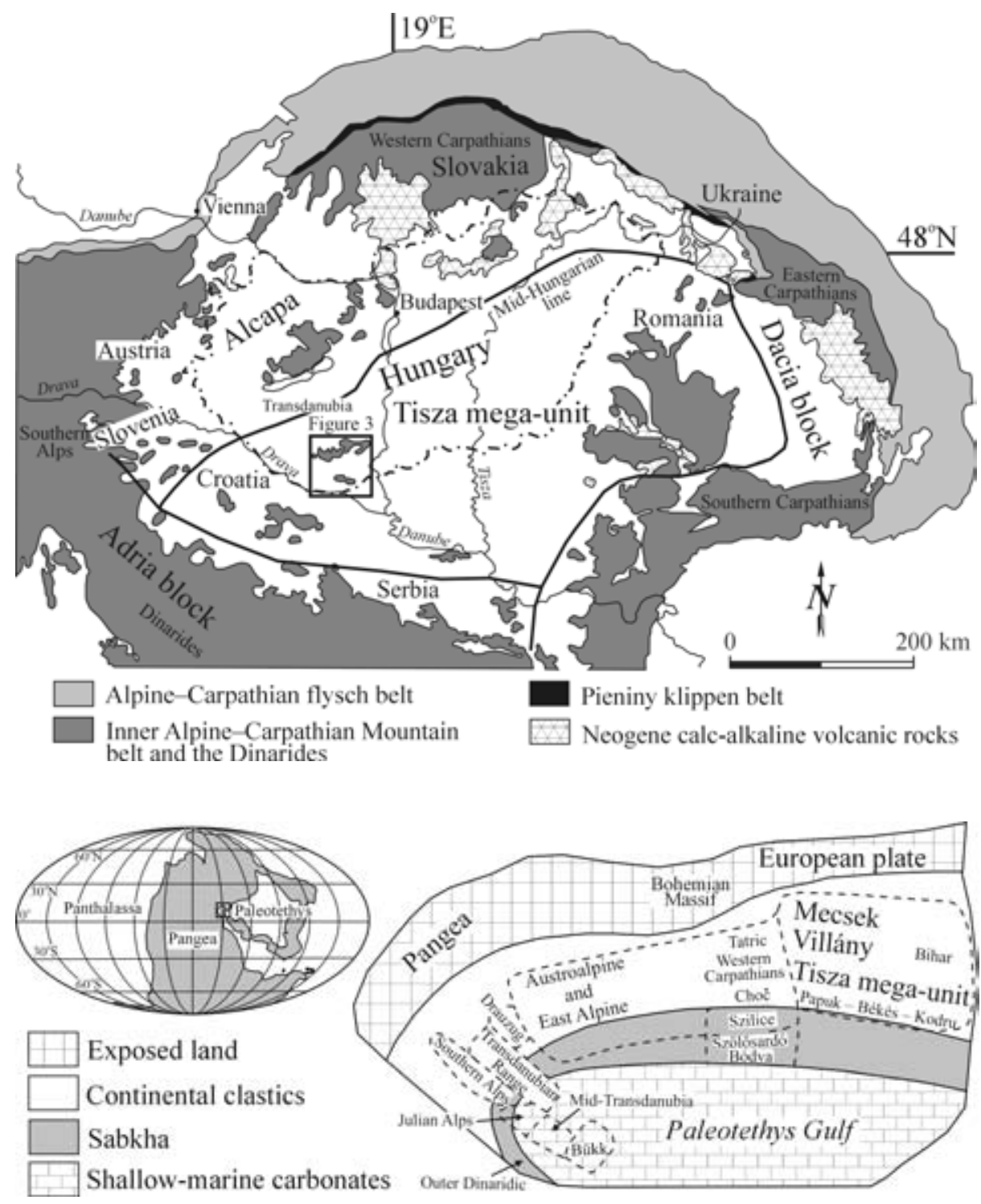

Figure 1. Geologic framework and major tectonic units of the Carpathian-Pannonian area, after Csontos et al. (1992, 2002).

Figure 2. Paleogeographic reconstruction for the Late Permian, modified from Haas et al. (1999). Index map shows the plate tectonic configuration for Pangea (ca. $255 \mathrm{Ma}$ ) with the location of the Carpathian-Pannonian area, after Golonka and Ford (2000).
Korpád Sandstone Formation). At the end of the Early Permian, deposition of continental siliciclastic sediments was punctuated by an intense acidic magmatic activity (Gyürüfü Rhyolite Formation). In the Late Permian, continental red beds (Cserdi Formation, Boda Siltstone Formation, and Kövágószőlős Formation) characterized the development of the Mecsek-Villány area (Fülöp, 1994; Barabás and Barabás-Stuhl, 1998; Haas et al., 1999). These formations tend to be barren in terms of their fauna, and accurate and reliable biostratigraphic correlations are often impossible. Therefore, correlation of the continental Paleozoic sequences of the Tisza mega-unit in the subsurface is very difficult (Barabás and Barabás-Stuhl, 1998).

Within the crystalline basement of the Tisza mega-unit, three terranes have been distinguished: (1) Slavonia-Drava unit, which can be subdivided into the Babócsa (or Görgeteg; after Fülöp, 1994) and Baksa subunits, (2) Kunság unit, including
Variscan granitoids of the Mórágy Complex, and (3) Békés unit (Szederkényi, 2001). In southern Transdanubia, the study area includes the western Mecsek Mountains, which are part of the Kunság unit, and the western flank of the Villány Mountains, which are part of the Slavonia-Drava unit. They are composed of Variscan crystalline basement and/or Carboniferous granitoids, late Paleozoic siliciclastic cover, and a Mesozoic sequence (Figs. 3 and 4).

The Paleozoic formations studied in this paper are the Téseny, Korpád, and Cserdi Formations (Figs. 4 and 5). The Téseny Formation (Pennsylvanian), which is interpreted as fluvial system deposits, unconformably overlies the crystalline basement (Babócsa and Baksa metamorphic complexes) and has a maximum thickness of $\sim 1500 \mathrm{~m}$. This formation is found partly in the western flank of the Villány Mountains and also in the Drava Basin. It is composed of conglomerate, sandstone, and 


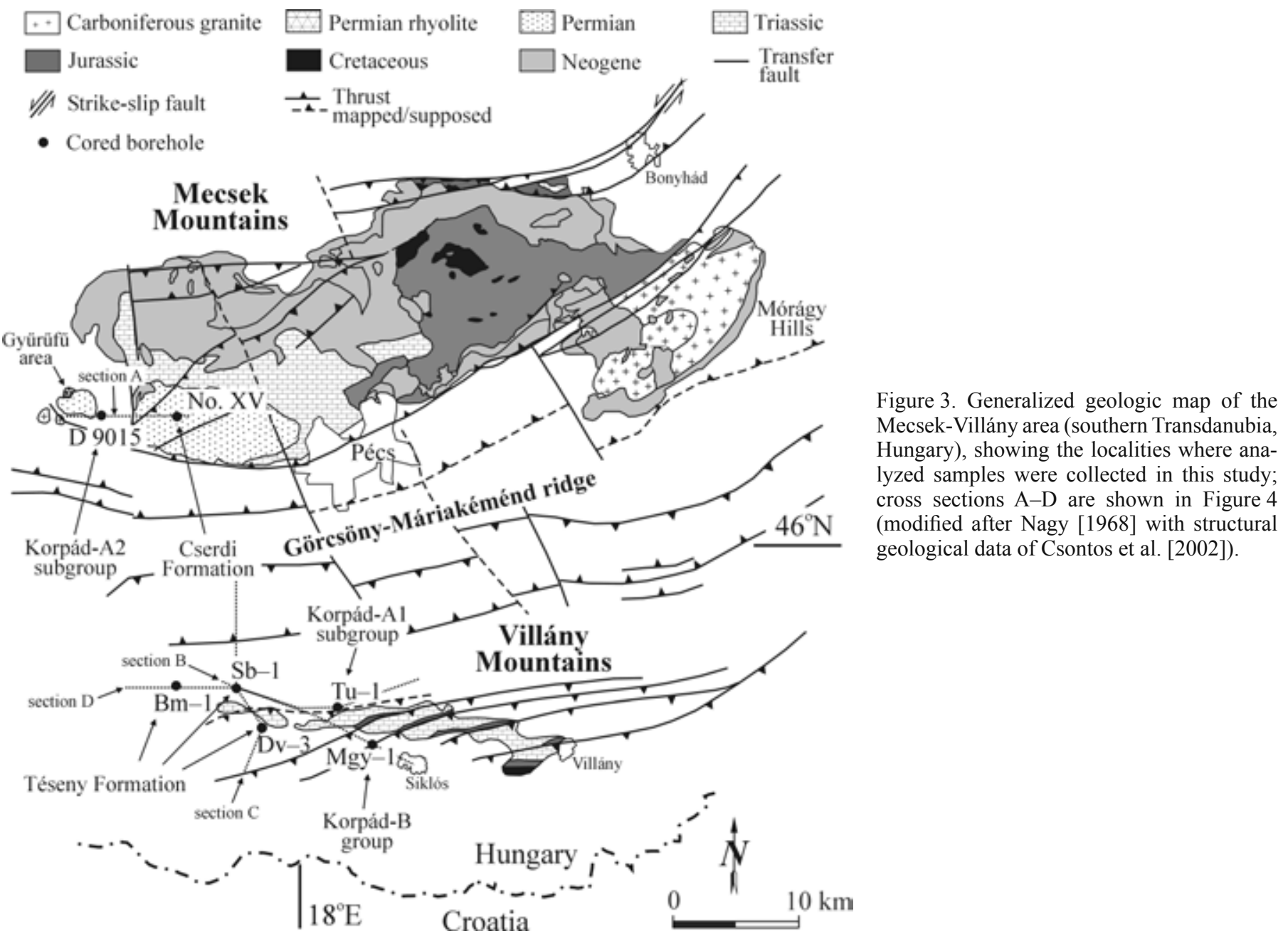

siltstone; shale and coal seams also occur (Jámbor, 1969; Hetényi and Ravasz-Baranyai, 1976; Varga et al., 2003). These rocks contain a Namurian-Westphalian flora composed of Pecopteris, Sphenopteris, Neuropteris, Alethopteris, Sphenophyllum, Annularia, Calamites assemblage and Westphalian palynomorphs (Hetényi and Ravasz-Baranyai, 1976). The alluvial Korpád Formation (Lower Permian) ranges up to $700 \mathrm{~m}$ in thickness and consists of polymictic basal conglomerate, breccia, sandstone, siltstone, and claystone. However, extreme variation in thickness has been documented (Balogh and Barabás, 1972; Fazekas, 1987; Barabás and Barabás-Stuhl, 1998). Rocks of this formation contain a sparse Lower Permian plant flora (e.g., Pecopteris, Voltzites) and a lowermost Permian microflora composed of Potonieisporites and Vittatina assemblage (Barabás and BarabásStuhl, 1998). The Cserdi Formation (Upper Permian) consists of up to $1000 \mathrm{~m}$ of polymictic conglomerate, sandstone, and siltstone beds representing debris flow-dominated alluvial fan deposits (Balogh and Barabás, 1972; Fazekas, 1987; Barabás and Barabás-Stuhl, 1998). Due to the lack of palynomorphs within these continental sediments, precise dating and biostratigraphic correlation among natural outcrops and boreholes is poorly constrained (Barabás and Barabás-Stuhl, 1998).

\section{SAMPLING AND ANALYTICAL METHODS}

The Pennsylvanian and Lower Permian formations occur in the subsurface in southern Transdanubia. Téseny rocks are known from numerous boreholes in the western flank of the Villány Mountains (Figs. 3-5), for example, in boreholes Bogádmindszent-1 (Bm-1), Diósviszló-1 (Dv-3), and Siklósbodony-1 (Sb-1). In the study area, the Lower Permian Korpád Sandstone was penetrated by boreholes Turony1 (Tu-1), Máriagy"ud-1 (Mgy-1), and Dinnyeberki 9015 (D 9015). The Upper Permian sediments crop out in the western part of the Mecsek Mountains, where a cored exploration borehole (No. XV) that penetrated Cserdi clastics was chosen for detailed observations (Figs. 3-5). A total of 72 sandstone and conglomerate-breccia core samples from these boreholes and 5 representative samples of pebble-sized gneiss clasts from borehole Mgy-1 were newly collected for this study (Table DR1). ${ }^{1}$ In addition, the results from previous petrological and geochemical studies of the Téseny Formation in this area (Varga and Szakmány, 2004; Varga et al., 2001, 2003, 2004) have been integrated into this paper ( 65 sandstone and conglomerate core samples; Tables DR1-DR3 [see footnote 1]). 
A

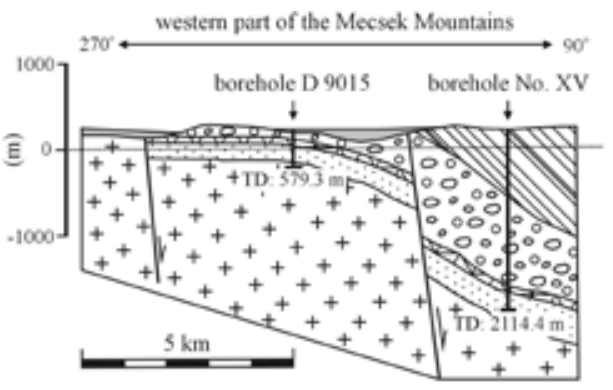

B

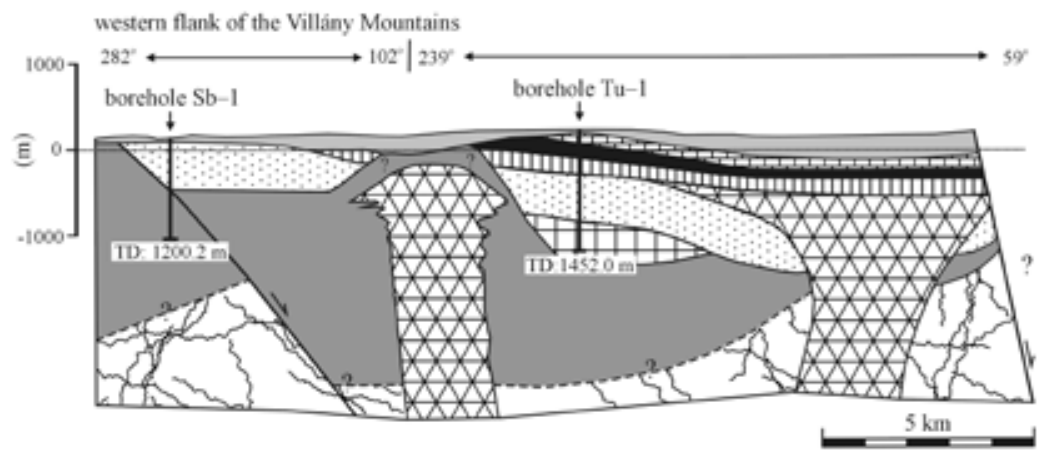

C

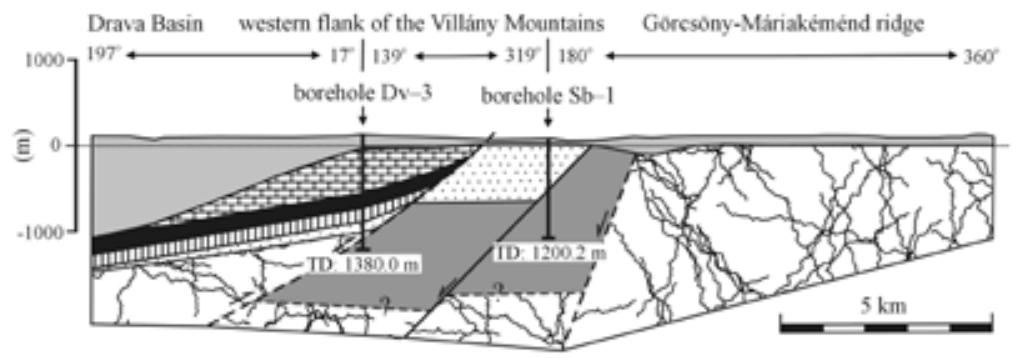

Carboniferous granite Mórágy granitoid rocks

Upper Carboniferous

Téseny Sandstone Formation

Lower Permian

Korpad Sandstone Formation

요요 Upper Permian

Cserdi Formation

Mesozoic sediments
Baksa-type metamorphites

Lower Permian

Turony Formation

Lower Permian

Gyürüfü Rhyolite Formation

Upper Permian

Boda Siltstone Formation

Lower Triassic

Jakabhegy Sandstone Formation

Middle Triassic

Patacs Siltstone Formation.

Hetvehely Dolomite Formation

監罣 Middle Triassic

Siklós Formation

亞垔 Upper Jurassic

Szársomlyó Limestone Formation

Upper Jurassic

Szársomlyó Limestone Formation, Lower-Middle Cretaceous

Nagyharsiny Limestone Formation

Miocene-Pannonian sediments

Fault

mapped/supposed

Thrust

mapped/supposed

D



Figure 4. Schematic cross sections of the Mecsek-Villány area, showing the stratigraphic and structural relationships in the field area (modified after Barabás and Barabás-Stuhl [1998] and Barabás-Stuhl [2000], personal commun.). TD—-total depth below the surface.

A total of 42 sandstone samples, including Téseny rocks, were selected for mineralogy (Table DR2). The mineralogical analyses of the whole rocks and their clay-size fraction were performed at the Department of Earth and Environmental Sciences of University of Veszprém (Hungary) by X-ray diffraction (XRD) using a Philips PW 1710 diffractometer.
Twenty-four representative rock samples and five gneiss clasts were used for geochemistry (Tables DR4-DR6, see footnote 1). Major and trace element ( $\mathrm{Rb}, \mathrm{Sr}, \mathrm{Ba}, \mathrm{Pb}, \mathrm{Y}, \mathrm{V}, \mathrm{Ni}$, $\mathrm{Zn}$, and $\mathrm{Co}$ ) abundances were established by $\mathrm{X}$-ray fluorescence (XRF) analysis using a Bruker AXS S4 Pioneer instrument in the laboratory of the University of Tübingen (Department of

${ }^{1}$ GSA Data Repository item 2007xxx, data tables DR1 to DR6, is available on the Web at http://www.geosociety.org/pubs/ft2007.htm. Requests may also be sent to editing@geosociety.org. 


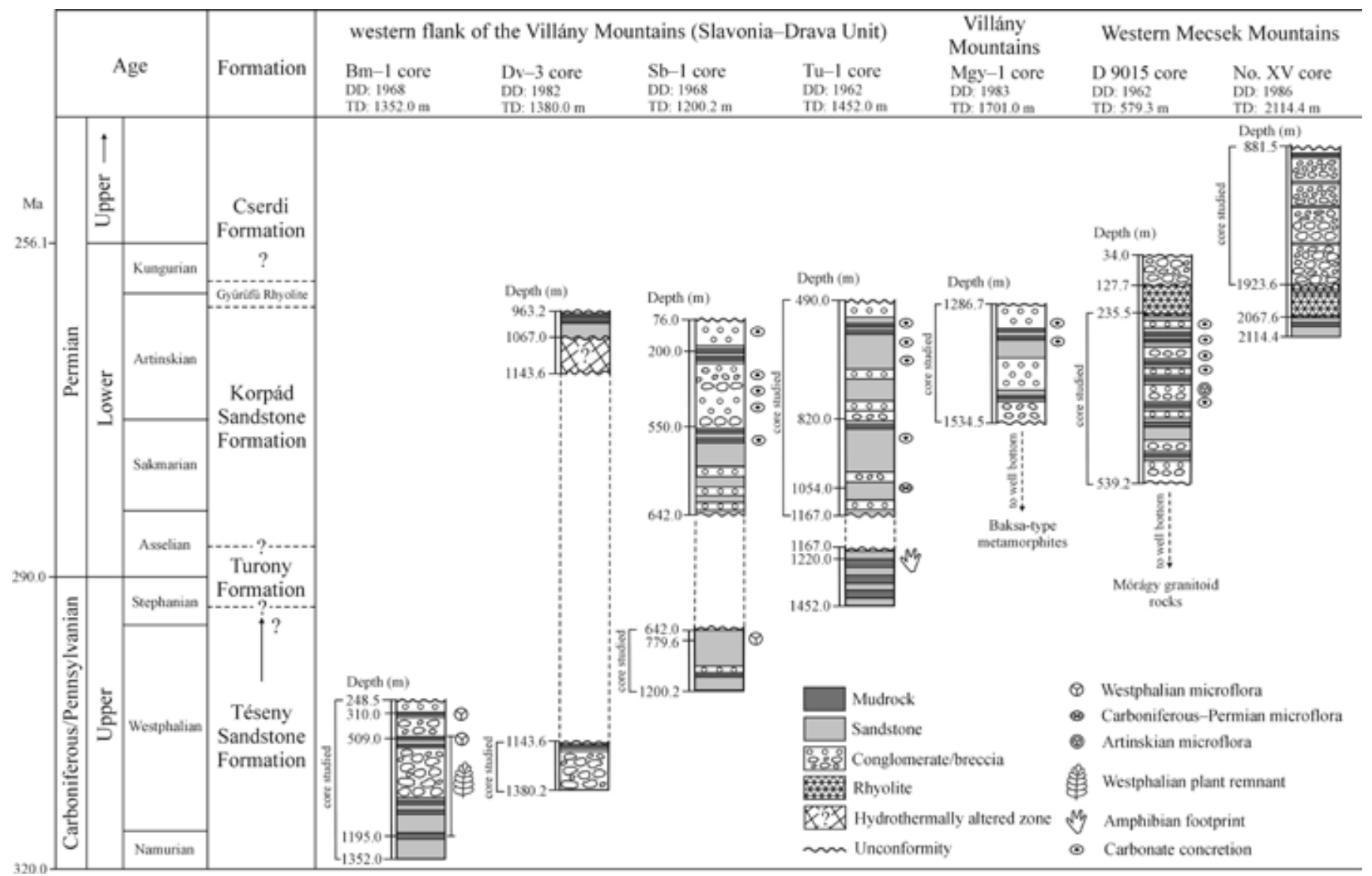

Figure 5. Schematic lithologic logs of the boreholes, showing the stratigraphic relationships of the cores studied and the position of the investigated section within the hole (modified after Fülöp [1994], Barabás and Barabás-Stuhl [1998], and Varga et al. [2004]). DD - date of drilling; TD - total depth below the surface.

Geochemistry, Germany). Chemical analyses of some minor elements were performed at the ACME Analytical Laboratories (Vancouver, Canada) using the following techniques: REE, Zr, and $\mathrm{Nb}$ were quantified by inductively coupled plasma-mass spectrometry (ICP-MS); Sc, Th, U, Ta, Hf, and Cr were quantified by neutron activation analysis (NAA). In additional, we have included the geochemical results of five gneiss and granitoid clasts collected from Téseny conglomerate to supplement our data set (Table DR6, see footnote 1). Analytical procedures are reported in Varga et al. (2003).

The results of previous petrological studies (Jámbor, 1969; Hetényi and Ravasz-Baranyai, 1976; Fazekas, 1987; Barabás and Barabás-Stuhl, 1998; Varga et al., 2001, 2003; Árgyelán, 2004, 2005) indicated that rocks of the Pennsylvanian and Lower Permian formations studied in this paper are not composed of detrital carbonate rock fragments. However, within these sedimentary rocks, fracture-controlled vein systems dominated by quartz and carbonates are present. In three samples (samples $15 / 17, \mathrm{MGY} / 7$, and $\mathrm{XV} / 55$ ) with more than $4.5 \mathrm{wt} \%$ of $\mathrm{CaO}$, increased $\mathrm{CaO}$ content is accompanied by increased LOI (loss on ignition) content (up to $11.41 \mathrm{wt} \%$ ), suggestive of the presence of postdepositional carbonate minerals. Chemical composition of these samples does not reflect the primary composition of detritus entering the depositional basin and cannot be used to interpret the provenance area and tectonic setting; therefore, these samples were avoided.

A complete description of the methods used for XRF and $\mathrm{XRD}$ analyses is available in the Appendix.

\section{RESULTS}

\section{Mineralogy and Petrography}

\section{Téseny Sandstone Formation}

The samples are poorly to moderately sorted lithic-feldspathic wacke to arenite and arkose (Folk, 1968). They are composed of variable amounts of mono- and polycrystalline quartz grains, plagioclase, K-feldspar, micas, chlorite, clays, Fe-oxides, and lithic grains, such as quartz-rich metamorphic, acidic-intermediate volcanic, granitoid, and siliciclastic rock fragments (Fig. 6A). Moreover, there are some accessory minerals such as zircon, tourmaline, apatite, rutile, and opaque grains. Illite-sericite 

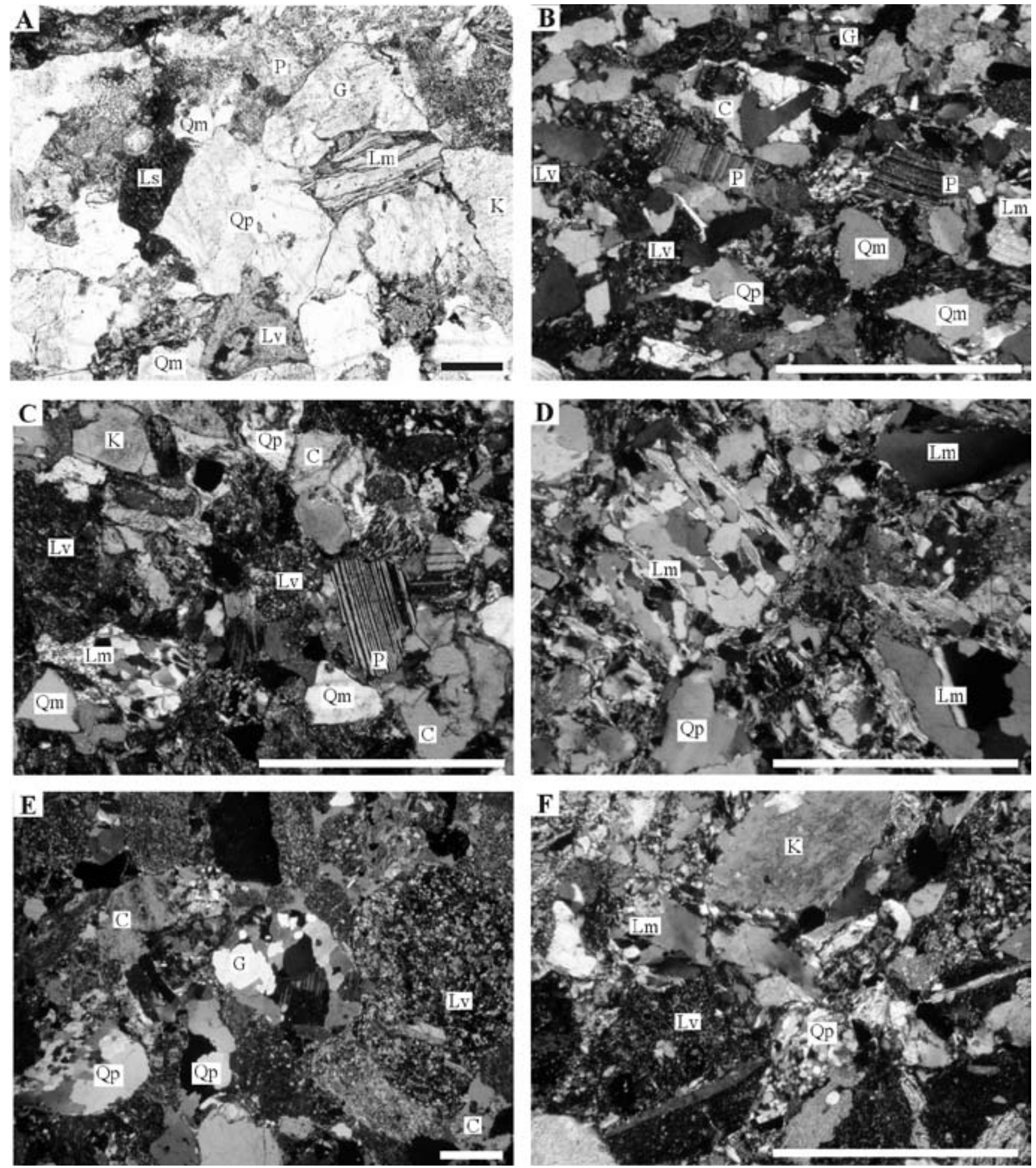

Figure 6. Thin-section photomicrographs of detrital components and textures in southern Transdanubia siliciclastic rocks. Scale bar in all photographs is $1 \mathrm{~mm}$. (A) Very coarse-grained Téseny sandstone (Bm-1 core). The framework exhibits dense packing generated by compaction. Plane-polarized light. (B) Medium-grained Korpád-A sandstone (Tu-1 core). Cross-polarized light. (C) Medium-grained Korpád-A sandstone (D 9015 core). Cross-polarized light. (D) Coarse-grained Korpád-B sandstone (Mgy-1 core) exhibiting a poorly sorted quartzose framework with metamorphic lithic fragments. Cross-polarized light. (E) Fine-pebble Korpád-A conglomerate (D 9015 core) exhibiting a great variety of clasts. Cross-polarized light. (F) Coarse-grained Cserdi sandstone (No. XV core). Cross-polarized light. Abbreviations: Qm-monocrystalline quartz; $\mathrm{Qp}$ - polycrystalline quartz; $\mathrm{P}$ - plagioclase; $\mathrm{K}$-K-feldspar; $\mathrm{M}$ - muscovite; Ls — siliciclastic rock fragment; Lm—metamorphic rock fragment; 
TABLE 1. PETROGRAPHIC DATA OF THE SANDSTONE SAMPLES

\begin{tabular}{|c|c|c|c|c|c|c|c|c|c|}
\hline Formation & Core & $\begin{array}{c}\text { Lithology } \\
\text { (Folk, 1968) }\end{array}$ & Sorting & Q types & F types & R types & Accessory minerals & $\begin{array}{c}\text { Diagenetic } \\
\text { replacement }\end{array}$ & Cements \\
\hline \multirow[t]{3}{*}{ Téseny } & $\mathrm{Bm}-1$ & $\begin{array}{l}\text { Arkose, subarkose, } \\
\text { sublitharenite }\end{array}$ & $\begin{array}{l}\text { Poor to } \\
\text { moderate }\end{array}$ & $\mathrm{Qp}>\mathrm{Qm}$ & $\begin{array}{l}\mathrm{K}>\mathrm{P} \text {, acidic } \\
\mathrm{K}: \text { microcline, } \\
\text { orthoclase }\end{array}$ & $\begin{array}{l}\text { Lv: acidic to intermediate, }(\mathrm{G}) \\
\text { Lm: Q-Ab-mu schist, paragneiss } \\
\text { Ls: mudrocks, chert }\end{array}$ & $\begin{array}{c}\text { mu, bio, chl, } \\
\text { zir, tou, ap, rut, (gar), } \\
\text { opaque minerals }\end{array}$ & $\begin{array}{c}\mathrm{P} \rightarrow \text { ill/ser, ka } \\
(\mathrm{K} \rightarrow \text { ill/ser, ka) } \\
\text { bio } \rightarrow \text { chl }\end{array}$ & $\begin{array}{l}\text { ill/ser, silica, } \\
\text { (chl, cc, dol, } \\
\text { sid) }\end{array}$ \\
\hline & Dv-3 & $\begin{array}{l}\text { Subarkose, } \\
\text { litharenite, } \\
\text { sublitharenite }\end{array}$ & Moderate & $Q p>Q m$ & $\begin{array}{l}\mathrm{K}>\mathrm{P} \text {, acidic } \\
\mathrm{K}: \text { microcline, } \\
\text { orthoclase }\end{array}$ & $\begin{array}{c}\text { Lv: acidic to intermediate } \\
\text { Lm: Q-Ab-mu schist, paragneiss } \\
\text { Ls: mudrocks, chert }\end{array}$ & $\begin{array}{l}\text { mu, bio, chl, tou, rut, } \\
\text { zir, ap, pyr, opaque } \\
\text { minerals }\end{array}$ & $\begin{array}{l}\mathrm{F} \rightarrow \text { ill/ser, ka } \\
\text { bio } \rightarrow \text { chl } \\
\text { hydrothermally } \\
\text { pyritized }\end{array}$ & $\begin{array}{l}\text { ill/ser, silica, } \\
\text { (Fe-oxide, chl) }\end{array}$ \\
\hline & $\mathrm{Sb}-1$ & $\begin{array}{l}\text { Litharenite, } \\
\text { sublitharenite }\end{array}$ & Poor & $\mathrm{Qp} \gg \mathrm{Qm}$ & $\begin{array}{c}A b>>K \\
K: \text { orthoclase }\end{array}$ & $\begin{array}{c}\text { Lv: (acidic to intermediate) } \\
\text { Lm: Q-Ab-mu schist, paragneiss, } \\
\text { quartzite } \\
\text { Ls: (mudrocks, chert) }\end{array}$ & $\begin{array}{c}\text { mu, bio, } \\
\text { chl, zir, rut, ap, } \\
\text { opaque minerals }\end{array}$ & $\begin{array}{l}\mathrm{P} \rightarrow \mathrm{ill} / \mathrm{ser} \\
\text { bio } \rightarrow \text { chl }\end{array}$ & $\begin{array}{l}\text { ill/ser, silica, } \\
\text { Fe-oxide, chl }\end{array}$ \\
\hline \multirow[t]{3}{*}{ Korpád } & $\begin{array}{l}\text { Tu-1 } \\
\text { (A1) }\end{array}$ & $\begin{array}{l}\text { Feldspathic-lithic } \\
\text { arenite, subarkose, } \\
\text { arkose }\end{array}$ & $\begin{array}{l}\text { Poor to } \\
\text { well }\end{array}$ & $\mathrm{Qm}>\mathrm{Qp}$ & $\begin{array}{l}\mathrm{K} \geq \mathrm{P} \text {, acidic } \\
\mathrm{K}: \text { orthoclase }\end{array}$ & $\begin{array}{l}\text { Lv: acidic to intermediate, }(G) \\
\text { Lm: low-grade metamorphites } \\
\text { Ls: mudrocks }\end{array}$ & $\begin{array}{l}\text { mu, bio, zir, rut, ap, } \\
\text { tou, mon, (gar), } \\
\text { opaque minerals }\end{array}$ & $\begin{array}{c}\mathrm{F} \rightarrow \text { ill/ser, ka } \\
\text { bio } \rightarrow \text { chl }\end{array}$ & $\begin{array}{l}\text { cc, dol, Fe- } \\
\text { oxide, ill/ser, } \\
\text { chl }\end{array}$ \\
\hline & $\begin{array}{l}\text { D } 9015 \\
\text { (A2) }\end{array}$ & $\begin{array}{c}\text { Arkose, subarkose, } \\
\text { lithic arenite }\end{array}$ & $\begin{array}{l}\text { Poor to } \\
\text { well }\end{array}$ & $\mathrm{Qm}>\mathrm{Qp}$ & $\begin{array}{l}\mathrm{K} \geq \mathrm{P} \text {, acidic } \\
\mathrm{K}: \text { orthoclase } \\
\text { (microcline) }\end{array}$ & $\begin{array}{c}\text { Lv: acidic to intermediate, }(\mathrm{G}) \\
\text { Lm: (Q-mu schist) } \\
\text { Ls: mudrocks }\end{array}$ & $\begin{array}{l}\text { mu, bio, chl } \\
\text { zir, tou, rut, (gar), } \\
\text { opaque minerals }\end{array}$ & $\begin{array}{l}\mathrm{F} \rightarrow \mathrm{ill} / \mathrm{ser} \\
\text { bio } \rightarrow \text { chl }\end{array}$ & $\begin{array}{l}\text { Fe-oxide, } \\
\text { ill/ser, cc, dol, } \\
\text { (chl) }\end{array}$ \\
\hline & $\begin{array}{l}\text { Mgy-1 } \\
\text { (B) }\end{array}$ & $\begin{array}{l}\text { Feldspathic-lithic } \\
\text { wacke, subarkose, } \\
\text { arkose }\end{array}$ & Poor & $\mathrm{Qm}>\mathrm{Qp}$ & $\begin{array}{c}\mathrm{K} \geq \mathrm{P} \\
\mathrm{K}: \text { orthoclase }\end{array}$ & $\begin{array}{c}\text { Lm: gneiss, Q-mu schist, Q-F-mu } \\
\text { schist } \\
\text { Ls: chert }\end{array}$ & $\begin{array}{l}\text { mu, (bio), rut, zir, } \\
\text { tou, opaque minerals }\end{array}$ & $\begin{array}{l}\mathrm{F} \rightarrow \text { ill/ser, ka, cc } \\
\text { recrystallized K } \\
\quad \text { bio } \rightarrow \text { chl }\end{array}$ & $\begin{array}{l}\text { Fe-oxide, } \\
\text { ill/ser, cc }\end{array}$ \\
\hline Cserdi & No. XV & $\begin{array}{l}\text { Litharenite, lithic- } \\
\text { feldspathic wacke }\end{array}$ & $\begin{array}{l}\text { Poor to } \\
\text { moderate }\end{array}$ & $\begin{array}{c}\text { Qm }>\text { Qp } \\
\text { (resorbed } \\
\text { Qm) }\end{array}$ & $\begin{array}{l}\mathrm{P}>\mathrm{K} \\
\mathrm{K} \text { : orthoclase, } \\
\text { microcline, } \\
\text { (sanidine, } \\
\text { perthite) }\end{array}$ & $\begin{array}{c}\text { Lv: acidic to intermediate, } \\
\text { mafic(?) glass, (G) } \\
\text { Lm: Q-mu schist, Q-F-mu schist, } \\
\text { sericite schist (orthogneiss) }\end{array}$ & $\begin{array}{l}\text { (mu), bio, tou, rut, } \\
\text { zir, ap, mon, (gar), } \\
\text { opaque minerals }\end{array}$ & $\begin{array}{l}\mathrm{Lm} \rightarrow \mathrm{chl} \\
\text { Lv glass } \rightarrow \text { chl } \\
\quad \text { bio } \rightarrow \text { chl }\end{array}$ & $\begin{array}{l}\text { Fe-oxide, cc, } \\
\text { dol, ill/ser, chl }\end{array}$ \\
\hline
\end{tabular}

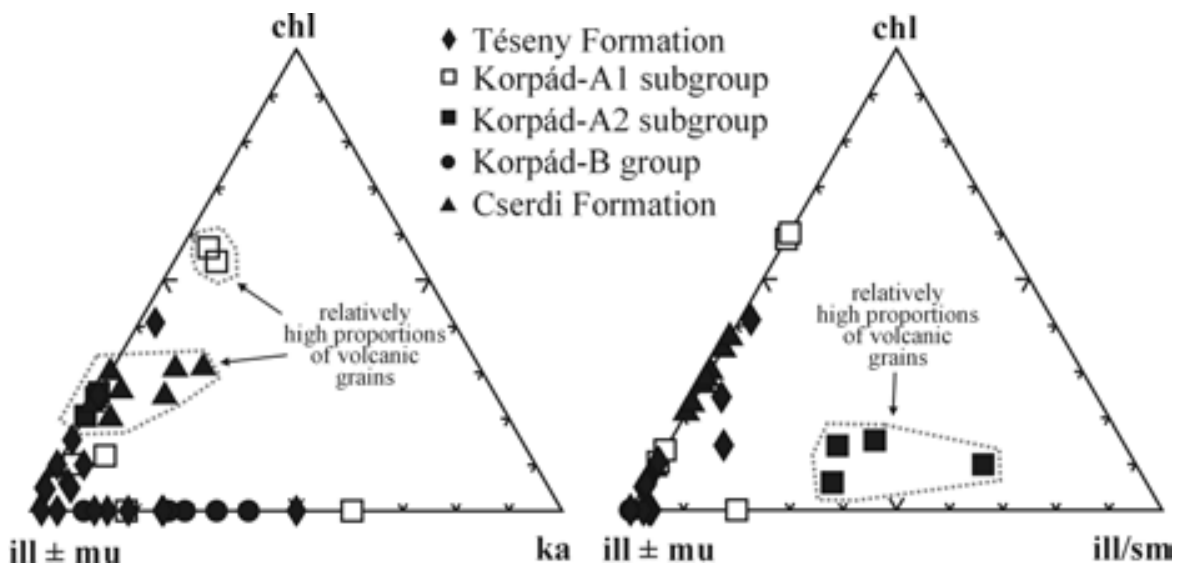

Figure 7. Triangular plots of sandstone samples based on relative abundance $(\%)$ in the clay fraction $(<2 \mu \mathrm{m})$ of clay minerals. Abbreviations: ill $\pm \mathrm{mu}$-illite \pm muscovite; chlchlorite; ka-kaolinite; ill/sm-mixed-layer illite-smectite. Clay-size X-ray diffraction (XRD) data are available in Table DR2 (see text footnote 1).

replacement of feldspar grains (mainly plagioclase) is typical. Illite-sericite, silica, and chlorite cements are common. Additionally, hematite, siderite, and rare calcite cements also occur (Table 1). The clay-mineral assemblage consists predominantly of illite \pm muscovite with minor proportions of chlorite with an $\mathrm{Fe}(\mathrm{II})$-rich interlayer, kaolinite, and mixed-layer illite-smectite (Fig. 7).

Greater amounts of K-feldspar and volcanic rock fragments are noted in boreholes Bm-1 and Dv-3. In borehole Sb-1, plagioclase-rich metamorphic lithic fragments are the main components, and K-feldspar and volcanic grains appear in low proportions.
The poorly to moderately sorted polymictic Téseny conglomerate samples are characterized by metamorphic (gneiss, quartz-muscovite-albite schist, phyllite, mylonite, metagranitoid, metaquartzite), sedimentary (mudrock, sandstone, chert), and acidic-intermediate volcanic (rhyolite, dacite, trachyandesite, andesite) rock clasts (Table 2 ).

\section{Korpád Sandstone Formation}

Two groups of Korpád clastics are recognized on the basis of particle composition. One is volcanic-rich (Korpád-A) sediment from boreholes Tu-1 and D 9015; the other is metamorphic lithicrich (Korpád-B) rock from borehole Mgy-1. 
TABLE 2. PETROGRAPHIC DATA OF THE CONGLOMERATE AND BRECCIA SAMPLES

\begin{tabular}{|c|c|c|c|c|c|c|c|}
\hline \multirow[t]{2}{*}{$\overline{\overline{\text { Formation }}}$} & \multirow[t]{2}{*}{ Core } & \multirow[t]{2}{*}{ Clast types } & \multirow[t]{2}{*}{ Roundness } & \multirow[t]{2}{*}{ Sorting } & \multirow[t]{2}{*}{ Fabric } & \multicolumn{2}{|c|}{ Grain size $(\mathrm{mm})$} \\
\hline & & & & & & Range & Average \\
\hline \multirow[t]{3}{*}{ Téseny } & $\mathrm{Bm}-1$ & $\begin{array}{c}\text { Rv—rhyolite, dacite, trachyandesite, andesite } \\
\text { Rm—gneiss, Q-mu schist, Q-mu-Ab schist, } \\
\text { phyllite, mylonite, metagranitoid, } \\
\text { metaquartzite/quartzite } \\
\text { Rs_-mudrock, sandstone, chert } \\
\text { Others—silicified caustobiolithic rocks, feldspar } \\
\text { megacryst }\end{array}$ & $\begin{array}{l}\text { (Subangular), } \\
\text { Subrounded, } \\
\text { (rounded) }\end{array}$ & Poor to well & Grain supported & $4-50$ & 14 \\
\hline & Dv-3 & $\begin{array}{c}\text { Rv_rhyolite, dacite, trachyandesite, andesite } \\
\text { Rm-gneiss, Q-mu schist, Q-mu-Ab schist, } \\
\text { phyllite, mylonite, metagranitoid, } \\
\text { metaquartzite/quartzite } \\
\text { Rs_-mudrock, sandstone, chert } \\
\text { Others—silicified caustobiolithic rocks, feldspar } \\
\text { megacryst }\end{array}$ & $\begin{array}{l}\text { Rounded, } \\
\text { well rounded }\end{array}$ & $\begin{array}{l}\text { Poor to } \\
\text { moderate }\end{array}$ & Grain supported & $6-80$ & 19 \\
\hline & $\mathrm{Sb}-1$ & $\begin{array}{c}\text { Rv_-(rhyolite, dacite, trachyandesite, andesite) } \\
\text { Rm-gneiss, Q-mu schist, Q-mu-Ab schist, } \\
\text { phyllite, mylonite, metagranitoid, } \\
\text { metaquartzite/quartzite } \\
\text { Rs_-(mudrock, sandstone, chert) }\end{array}$ & $\begin{array}{l}\text { Angular, } \\
\text { subangular, } \\
\text { (subrounded) }\end{array}$ & $\begin{array}{l}\text { Poor (to } \\
\text { moderate) }\end{array}$ & $\begin{array}{l}\text { Grain supported, } \\
\text { slightly oriented } \\
\text { texture }\end{array}$ & $4-45$ & 12 \\
\hline \multirow[t]{3}{*}{ Korpád } & $\begin{array}{l}\text { Tu-1 } \\
\text { (A1) }\end{array}$ & $\begin{array}{c}\text { Rv_recrystallized acidic-intermediate volcanites } \\
\mathrm{Rm} \text {-P gneiss, Q-mu schist, metaquartzite, } \\
\text { metasandstone, } \\
\text { (granitoid/metagranitoid) } \\
\text { Rs_-(resedimented claystone, wacke, chert) }\end{array}$ & Subrounded & $\begin{array}{c}\text { Moderate to } \\
\text { well }\end{array}$ & Grain supported & $3-18$ & 5 \\
\hline & $\begin{array}{c}\text { D } 9015 \\
(A 2)\end{array}$ & $\begin{array}{c}\text { Rv-recrystallized acidic-intermediate volcanites, } \\
\text { (andesite) } \\
\text { Rm-P gneiss, Q-mu schist, metaquartzite, } \\
\text { metasandstone, } \\
\text { (granitoid/metagranitoid) } \\
\text { Rs-(resedimented claystone, wacke, chert) }\end{array}$ & , Subrounded & Poor & Grain supported & $3-30$ & 12 \\
\hline & $\begin{array}{l}\text { Mgy-1 } \\
\text { (B) }\end{array}$ & $\begin{array}{c}\mathrm{Rm} \text {-gneiss, quartzite, (garnet-bearing mica } \\
\text { schist), } \\
\text { (metagranitoid) }\end{array}$ & $\begin{array}{l}\text { Angular, } \\
\text { (subrounded, } \\
\text { rounded) }\end{array}$ & Very poor & $\begin{array}{l}\text { Matrix supported } \\
\text { slightly oriented } \\
\text { texture }\end{array}$ & $4-70$ & 15 \\
\hline Cserdi & No. XV & $\begin{array}{c}\text { Rv_rhyolite, dacite, (andesite) } \\
\mathrm{Rm} \text { - } \text { (gneiss, Q-mu schist, Q-mu-F schist, } \\
\text { mylonite, metaquartzite/quartzite) } \\
\text { (granitoid/metagranitoid) }\end{array}$ & $\begin{array}{l}\text { Subangular, } \\
\text { subrounded }\end{array}$ & $\begin{array}{l}\text { Poor to } \\
\text { moderate }\end{array}$ & $\begin{array}{l}\text { Grain supported } \\
\text { (matrix supported) } \\
\quad \text { (grading) }\end{array}$ & $4-110$ & 25 \\
\hline
\end{tabular}

Korpád-A sandstones are poorly to well-sorted feldspathiclithic arenite to subarkose and arkose (Folk, 1968). Most of the studied rocks are rich in Fe-oxides. They are composed of monoand polycrystalline quartz, plagioclase, K-feldspar, acidicintermediate volcanic grains, and lesser amounts of granitoid and metamorphic rock grains and recycled mudrock fragments (Figs. 6B and 6C). Intermediate hypabyssal lithic fragments are occasionally present. Detrital muscovite and a small proportion of biotite also occur in most of the samples. Accessories are zircon, monazite, rutile, apatite, tourmaline, opaque grains, and rare garnet. Calcite and dolomite cements are common. Additionally, illite-sericite and chlorite cements also occur (Table 1). In the middle part of borehole Tu-1 and in the lower part of borehole D 9015, greater amounts of granitic and metamorphic rock fragments and $\mathrm{K}$-feldspar grains are present.

Korpád-A samples can be subdivided into two subgroups on the basis of clay-mineral assemblage. In the western flank of the Villány Mountains, samples from borehole Tu-1 (KorpádA1) consist dominantly of illite \pm muscovite and chlorite with a Mg-rich interlayer. Minor proportions of kaolinite and mixedlayer illite-smectite also occur (Fig. 7). In the western Mecsek Mountains, samples from borehole D 9015 (Korpád-A2) are composed of variable amounts of illite \pm muscovite, ISII (i.e. illite/smectite/illite/illite using Wantanabe [1981]'s nomenclature) ordered variety of mixed-layer illite-smectite and chlorite, with an Fe(II)-rich interlayer (Fig. 7). As discussed in detail in the following, compositional differences between the subgroups can be explained as a product of diagenesis.

Korpád-B samples are poorly sorted feldspathic-lithic wacke to subarkose and arkose (Folk, 1968) and contain angular detrital grains. They consist mostly of mono- and polycrystalline quartz, plagioclase, K-feldspar, muscovite, and lithic fragments with minor biotite, opaque grains, Fe-oxides, clayey matrix, and calcite cement. Tourmaline, zircon, and rutile occur as accessories. Feldspar grains are partially or totally altered and replaced by clay minerals or calcite (Table 1). The lithic fragments are dominated by unstable detritus derived from quartz-rich metamorphic rocks (Fig. 6D). Illite \pm muscovite and kaolinite are the only phyllosilicates present in the clay-mineral assemblage (Fig. 7).

In Korpád-A conglomerate samples, acidic-intermediate volcanic and metamorphic (plagioclase gneiss, quartz-muscovite schist, metaquartzite, metasandstone) rock clasts are the main components; felsic plutonic (granitoid/metagranitoid), and intraformational sedimentary (claystone, wacke) lithic clasts are 
subordinate. A small number of intermediate hypabyssal rock clasts are also present (Table 2).

The matrix-supported Korpád-B breccia is characterized by a predominance of metamorphic clasts. Gneiss and quartzite clasts are the main components; garnet-bearing mica schist and metagranitoid clasts are subordinate (Table 2). Volcanic rock clasts were not identified in this unit.

\section{Cserdi Formation}

The samples are poorly to moderately sorted lithicfeldspathic wacke to litharenite (Folk, 1968) and contain angular to subangular detrital grains. Acidic volcanic lithic fragments and feldspar (more plagioclase than K-feldspar) grains are prominent; quartz grains are subordinate in most of the samples (Fig. 6F). In the lower part of this unit, resorbed monocrystalline quartz grains are locally abundant. Polycrystalline quartz grains, intermediate volcanic, metamorphic, and granitoid lithic fragments appear in low proportions. Typical accessory minerals are tourmaline, rutile, zircon, apatite, monazite, opaque grains, and rare garnet. Illite-sericite, chlorite, calcite, and dolomite occur as cement, in some cases, replaced by other minerals. Locally, metamorphic grains and volcanic glass fragments are strongly chloritized (Table 1). Based on XRD, anhydrite is present only in sample XV/55. The clay-mineral assemblage includes illite \pm muscovite, swelling chlorite, and occasionally minor amounts of kaolinite (Fig. 7).

The clast-supported conglomerates with volcanic pebbles are the main lithofacies of this formation, which has infiltrated silty and sandy matrix that has grains with the same immature detrital compositions as interbedded sandstones. Volcanic rock (rhyolite, dacite, and lesser amounts of andesite) clasts are the main components; metamorphic (quartz-muscovite schist, quartzmuscovite-feldspar schist, mylonite, metagranitoid, gneiss) and granitoid clasts are subordinate (Table 2).

\section{Gneiss and Granitoid Clasts}

Téseny Conglomerate. Nonfoliated and foliated gneissclasts have typical gneissic structure and coarse-grained granoblastic texture. Some gneiss samples are slightly mylonitized. Rock-forming minerals are quartz, plagioclase, K-feldspar, muscovite, and biotite. Strong alteration of feldspars (mainly sericitization) is typical. In certain cases, K-feldspar shows some relic magmatic features such as perthitic intergrowths and tabular shape. Newly grown minerals, including welldeveloped muscovite flakes, are common (Fig. 8A). Biotite is generally highly degraded to chlorite, sericite, white mica, and opaque minerals. Accessories are apatite, zircon, rutile, opaque grains, and rare strongly altered garnet.

Granitoid clasts, including aplite and quartz diorite, are present as a small proportion of total clasts but are persistent in boreholes Bm-1 and Dv-3. Aplite clasts have fine-grained panallotriomorphic-granular (i.e. all the observed minerals are xenomorphic) that is occasionally obliterated by mylonitization. Rock-forming minerals are quartz, K-feldspar, and plagioclase.
Few grains of muscovite also occur. Accessory minerals are zircon, apatite, and rare rutile. K-feldspars are relatively fresh or weakly sericitized; the plagioclases are frequently altered to sericite. Quartz diorite clasts have hypidiomorphic-granular texture and contain quartz, plagioclase, and muscovite as major constituents. Biotite occurs as a subordinate mineral with accessory apatite, zircon, and titanite. Plagioclase is partially altered and replaced by sericite and clay minerals. Biotite is generally highly degraded to chlorite. Siderite and pyrite were also identified as accessories in this clast type. Their presence is due to hydrothermal mineralization.

Korpád-B Breccia. Gneiss clasts from Korpád-B breccia show great similarity concerning mineralogical composition; however, their two types are recognized on the basis of proportion of certain minerals and rock texture. One is a foliated, mica-rich biotite gneiss (type I; Fig. 8B); the other is a mica-poor gneiss/ metagranite (type II), which generally is nonfoliated (Fig. 8C). Type I gneiss clasts have lepidoblastic, lepido-granoblastic, occasionally blasto-poikilitic texture. Type II gneiss clasts have granoblastic, lepido-granoblastic, occasionally blasto-poikilitic texture. Original igneous textures are commonly recognizable in this clast type. Stages of increasing metamorphic recrystallization from none (granite protolith) to complete (granoblastic gneiss with newly grown crystals) were observed.

Their rock-forming minerals are quartz, plagioclase, $\mathrm{K}$ feldspar, and two micas. Plagioclase crystals are generally subhedral and myrmekitic. In certain cases, their lamellar twinning is recognizable. Strong alteration of plagioclases is typical. Kfeldspar crystals are mostly euhedral or subhedral. These grains are predominantly untwinned; however, twinned grains are also present in inconsiderable amounts. Occasionally perthitic intergrowths were observed. They are partially altered and replaced by sericite; in some cases, they are strongly sericitized along the grain boundaries. Muscovite and biotite coexist in most samples, although biotite is generally highly degraded to chlorite, white mica, and opaque minerals. In a few cases, relic magmatic textures such as lath-shaped or tabular habit of biotite were preserved. Kink-band structure and undulose extinction are common on white mica bunches. Zircon, apatite, rutile, titanite, ilmenite, and rare tourmaline occur as accessories. They appear as inclusions or as a matrix mineral. Calcite and hematite are widespread as secondary minerals in some specimens.

\section{Geochemistry}

Chemical data of sandstone and clast samples studied from southern Transdanubia are reported in Tables DR3-DR6 (see footnote 1). In this study, the median is used as the summary statistical parameter (Table 3) because it is independent of outliers, and this value provides a robust estimate of central tendency for data sets drawn from a population with an unknown distribution pattern (Cox et al., 1995; Lee, 2002). Values of some elemental ratios and associated parameters are listed in Table 4 for sandstones and in Table 5 for clasts. 

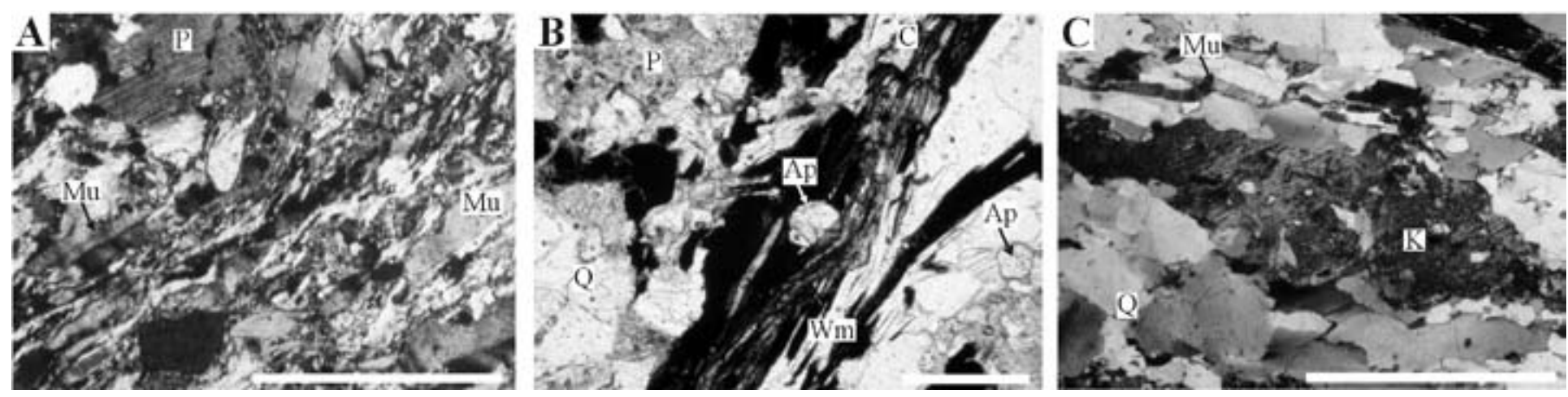

Figure 8. Thin-section photomicrographs of gneiss clasts. Scale bar in all photographs is $1 \mathrm{~mm}$. (A) Foliated Téseny gneiss clast (Sb-1 core). Crosspolarized light. (B) type-I Korpád-B gneiss clast (Mgy-1 core). Plane-polarized light. (C) type-II Korpád-B gneiss clast (Mgy-1 core). Cross-polarized light. Abbreviations: Q — quartz; P—plagioclase; K—K-feldspar; Mu—muscovite; Ap—apatite; Wm—white mica; C-carbonate.

TABLE 3. MEDIAN VALUES FOR SANDSTONE SAMPLES

Unit Téseny Korpád-A1 Korpád-A2 Korpád-B Cserdi UCC

\begin{tabular}{|c|c|c|c|c|c|c|}
\hline No. & (18) & (6) & (3) & (4) & (8) & \\
\hline$\overline{\mathrm{SiO}_{2}}$ & 78.89 & 73.77 & 72.51 & 73.06 & 72.12 & 66 \\
\hline $\mathrm{TiO}_{2}$ & 0.35 & 0.38 & 0.66 & 0.54 & 0.59 & 0.68 \\
\hline $\mathrm{Al}_{2} \mathrm{O}_{3}$ & 11.96 & 13.06 & 14.02 & 15.36 & 13.56 & 15.2 \\
\hline $\mathrm{Fe}_{2} \mathrm{O}_{3}$ & 2.49 & 2.19 & 4.01 & 2.97 & 4.15 & 5.03 \\
\hline $\mathrm{MnO}$ & 0.04 & 0.07 & 0.07 & 0.02 & 0.04 & 0.08 \\
\hline $\mathrm{MgO}$ & 1.08 & 1.46 & 1.95 & 1.12 & 1.71 & 2.2 \\
\hline $\mathrm{CaO}$ & 0.29 & 2.69 & 2.26 & 0.76 & 0.61 & 4.2 \\
\hline $\mathrm{Na}_{2} \mathrm{O}$ & 1.24 & 4.27 & 3.49 & 1.73 & 3.49 & 3.9 \\
\hline $\mathrm{K}_{2} \mathrm{O}$ & 3.31 & 1.56 & 2.12 & 3.37 & 3.09 & 3.4 \\
\hline $\mathrm{P}_{2} \mathrm{O}_{5}$ & 0.06 & 0.09 & 0.09 & 0.14 & 0.15 & 0.15 \\
\hline $\mathrm{Rb}$ & 133 & 63 & 87 & 123 & 148 & 112 \\
\hline $\mathrm{Sr}$ & 69 & 210 & 196 & 65 & 134 & 350 \\
\hline $\mathrm{Ba}$ & 546 & 388 & 428 & 536 & 552 & 550 \\
\hline Th & 8.1 & 9.0 & 6.8 & 7.9 & 12.0 & 10.7 \\
\hline$U$ & 2.5 & 2.6 & 1.9 & 1.9 & 3.3 & 2.8 \\
\hline $\mathrm{Zr}$ & 94 & 180 & 157 & 174 & 179 & 190 \\
\hline $\mathrm{Hf}$ & 3 & 6 & 5 & 6 & 6 & 6 \\
\hline $\mathrm{Nb}$ & 8 & 8 & 9.3 & 7 & 11 & 12 \\
\hline Y & 18 & 24 & 21 & 28 & 34 & 22 \\
\hline Sc & 6.0 & 7.8 & 9.3 & 7.8 & 10.2 & 13.6 \\
\hline V & N.D. & 40 & 47 & 37 & 64 & 107 \\
\hline $\mathrm{Cr}$ & 42 & 34 & 45 & 30 & 95 & 83 \\
\hline Co & 6 & 5 & 9 & 3 & 10 & 17 \\
\hline $\mathrm{Ni}$ & 16 & L.D. & L.D. & L.D. & 41 & 44 \\
\hline La & 20 & 31 & 23 & 30 & 30 & 30 \\
\hline $\mathrm{Ce}$ & 36 & 46 & 52 & 58 & 64 & 64 \\
\hline $\mathrm{Pr}$ & N.D. & 5.5 & 6.1 & 6.7 & 7.4 & 7.1 \\
\hline $\mathrm{Nd}$ & N.D. & 25 & 24 & 25 & 30 & 26 \\
\hline $\mathrm{Sm}$ & 2.9 & 4.5 & 4.5 & 5.1 & 6.3 & 4.5 \\
\hline $\mathrm{Eu}$ & 0.50 & 0.94 & 0.94 & 1.01 & 1.11 & 0.88 \\
\hline $\mathrm{Gd}$ & N.D. & 3.7 & 3.3 & 3.9 & 5.1 & 3.8 \\
\hline $\mathrm{Tb}$ & N.D. & 0.62 & 0.52 & 0.64 & 0.86 & 0.64 \\
\hline Dy & N.D. & 3.2 & 3.0 & 3.8 & 4.9 & 3.5 \\
\hline Ho & N.D. & 0.7 & 0.6 & 0.8 & 1.0 & 0.8 \\
\hline $\mathrm{Er}$ & N.D. & 2.1 & 1.8 & 2.0 & 2.7 & 2.3 \\
\hline $\mathrm{Tm}$ & N.D. & 0.30 & 0.28 & 0.33 & 0.43 & 0.33 \\
\hline $\mathrm{Yb}$ & 1.2 & 1.9 & 1.6 & 2.0 & 2.6 & 2.2 \\
\hline Lu & 0.13 & 0.30 & 0.25 & 0.32 & 0.39 & 0.32 \\
\hline
\end{tabular}

Notes: Major oxides are in wt\%, trace elements, in ppm. Total iron is listed as $\mathrm{Fe}_{2} \mathrm{O}_{3}$. Major element data are recalculated volatilefree. No.-number of samples; N.D.—no data; L.D.-lower detection limit; UCC-upper continental crust (McLennan, 2001).

\section{Geochemical Characteristics of the Sandstone Samples}

Using the chemical classification scheme of Pettijohn et al. (1972), the Téseny and Korpád-B samples are classified as arkose and litharenite (Fig. 9). Korpád-A and Cserdi samples are classified mainly as graywacke and litharenite. Moreover, if we consider this diagram in the light of petrographic observations,
TABLE 4. ELEMENTAL RATIOS AND PARAMETERS FOR SANDSTONES

\begin{tabular}{|c|c|c|c|c|c|c|}
\hline $\begin{array}{l}\text { Unit } \\
\text { No. }\end{array}$ & $\begin{array}{c}\text { Téseny } \\
\text { (18) }\end{array}$ & $\begin{array}{c}\text { Korpád-A1 } \\
\text { (6) }\end{array}$ & $\begin{array}{c}\text { Korpád-A2 } \\
\text { (3) }\end{array}$ & $\begin{array}{c}\text { Korpád-B } \\
\text { (4) }\end{array}$ & $\begin{array}{c}\text { Cserdi } \\
\text { (8) }\end{array}$ & IUCC \\
\hline Th/Sc & 1.34 & 1.15 & 0.73 & 1.01 & 1.18 & 0.79 \\
\hline $\mathrm{La} / \mathrm{Sc}$ & 3.25 & 4.01 & 2.43 & 3.80 & 2.91 & 2.21 \\
\hline $\mathrm{Co} / \mathrm{Th}$ & 0.75 & 0.52 & 1.32 & 0.39 & 0.86 & 1.59 \\
\hline $\mathrm{Cr} / \mathrm{Th}$ & 5.16 & 3.81 & 6.62 & 3.80 & 7.92 & 7.76 \\
\hline $\mathrm{Cr} / \mathrm{Zr}$ & 0.44 & 0.19 & 0.29 & 0.17 & 0.53 & 0.44 \\
\hline $\mathrm{La} / \mathrm{Co}$ & 3.25 & 6.65 & 2.51 & 9.56 & 2.85 & 1.76 \\
\hline $\mathrm{Cr} / \mathrm{Ni}$ & 2.63 & N.D. & N.D. & N.D. & 2.32 & 1.89 \\
\hline $\mathrm{La}_{\mathrm{N}} / \mathrm{Sm}_{\mathrm{N}}$ & 4.23 & 4.37 & 3.16 & 3.70 & 2.97 & 4.20 \\
\hline$L a_{N} / Y b_{N}$ & 10.98 & 10.86 & 9.60 & 10.14 & 7.59 & 9.21 \\
\hline $\mathrm{Gd}_{N} / \mathrm{Yb}_{\mathrm{N}}$ & N.D. & 1.55 & 1.67 & 1.60 & 1.57 & 1.40 \\
\hline$\Sigma$ REE & 60 & 126 & 121 & 139 & 156 & 146 \\
\hline $\mathrm{Eu} / \mathrm{Eu}^{*}$ & N.D. & 0.70 & 0.75 & 0.69 & 0.60 & 0.65 \\
\hline
\end{tabular}

Notes: $\mathrm{La}_{N} / \mathrm{Sm}_{N}, \mathrm{La}_{N} / \mathrm{Yb}_{N}$, and $\mathrm{Gd}_{N} / \mathrm{Yb}_{\mathrm{N}}$ ratios were calculated from chondrite-normalized values. $\Sigma$ REE were calculated from concentrations of each element analyzed in ppm. Eu/Eu* represents the Eu anomaly according to the method of McLennan (1989). No.-number of samples; N.D.-no data; REE-rare earth element; UCC_-upper continental crust (McLennan, 2001).

it would emerge that the high $\mathrm{Na}_{2} \mathrm{O} / \mathrm{K}_{2} \mathrm{O}$ values, corresponding to the graywacke field, reflect the abundance of volcanic rock fragments and plagioclase grains. The low $\mathrm{Na}_{2} \mathrm{O} / \mathrm{K}_{2} \mathrm{O}$ values of some arkosic samples suggest that their behavior is controlled by the high mobility of $\mathrm{Na}_{2} \mathrm{O}$, especially during chemical weathering, diagenesis, and secondary alteration processes (Gaillardet et al., 1999; McLennan, 2001; Varga and Szakmány, 2004).

The sandstone samples collected for this study show moderate variations for $\mathrm{SiO}_{2}$ and $\mathrm{Al}_{2} \mathrm{O}_{3}$. Medians of $\mathrm{SiO}_{2}$ range from $72.12 \mathrm{wt} \%$ for Cserdi samples to $78.89 \mathrm{wt} \%$ for Téseny rocks. On average, $\mathrm{Al}_{2} \mathrm{O}_{3}$ content of the sandstone units is widely uniform, and medians lie in a narrow range from $11.96 \mathrm{wt} \%$ for Téseny Formation to $15.36 \mathrm{wt} \%$ for Korpád-B group (Table 3). In comparison with the upper continental crust (McLennan, 2001), which provides a consistent normalizing scheme for sandstone geochemistry (Floyd et al., 1991; Gaillardet et al., 1999; Zimmermann and Bahlburg, 2003), all the samples studied are slightly enriched in $\mathrm{SiO}_{2}$ (Fig. 10A). Apart from the KorpádA group, sandstone units analyzed have similar median values of $\mathrm{K}_{2} \mathrm{O}$ abundance to upper continental crust. In addition, they are depleted in $\mathrm{TiO}_{2}, \mathrm{Al}_{2} \mathrm{O}_{3}, \mathrm{Fe}_{2} \mathrm{O}_{3}, \mathrm{MnO}, \mathrm{MgO}, \mathrm{CaO}, \mathrm{Na}_{2} \mathrm{O}$, and 
TABLE 5. ASSOCIATED PARAMETERS OF GNEISS AND GRANITOID CLASTS

\begin{tabular}{|c|c|c|c|c|c|c|c|c|c|c|}
\hline $\begin{array}{l}\text { Sample } \\
\text { number }\end{array}$ & Gn1 & Gn2 & Gn3 & $\overline{\mathrm{Apl}}$ & $\overline{Q d i}$ & $\begin{array}{c}\text { Gn4 } \\
\text { Type II }\end{array}$ & $\begin{array}{c}\text { Gn5 } \\
\text { Type II }\end{array}$ & $\begin{array}{c}\text { Gn6 } \\
\text { Type I }\end{array}$ & $\begin{array}{c}\text { Gn7 } \\
\text { Type I }\end{array}$ & $\begin{array}{c}\text { Gn8 } \\
\text { Type I-II }\end{array}$ \\
\hline$\overline{\mathrm{A} / \mathrm{CNK}}$ & 1.55 & 1.31 & 1.42 & 1.10 & 1.65 & 2.01 & 1.84 & 2.09 & 2.28 & 2.29 \\
\hline & T.6/ & 1.45 & 1.5 & & 81 & 2.1 & & & +6 & .48 \\
\hline $\mathrm{K}_{2} \mathrm{O}$ & 1.77 & 2.15 & 1.92 & 0.5 & 34 & 1.0 & 1.45 & 0.65 & 0.43 & 0.42 \\
\hline & 1.51 & 1.57 & 2.10 & 4.9 & 10 & $2.5 \mathrm{C}$ & 2.8 & 2.87 & 2.83 & 2.70 \\
\hline & 8.11 & 3.15 & 8.11 & 50.01 & 5.41 & 2.92 & 2.95 & 5.51 & 5.28 & 2.38 \\
\hline & N.D. & N.D. & N.D. & & N.D. & 1.05 & 1.06 & 1.43 & 1.46 & N.D. \\
\hline TIV & 54.353 & 36.16 & 49.42 & 108.23 & 36.058 & 84.00 & 51.62 & 150.65 & 104.73 & 56.66 \\
\hline$E u^{*}$ & N.D. & N.D. & N.D. & N.D. & N.D. & 0.36 & 0.60 & 0.63 & 0.51 & N.D. \\
\hline $\mathrm{O}_{3}$ & & 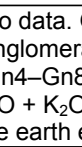 & & & & 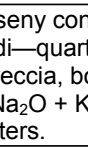 & & - & & ; ;pl- \\
\hline
\end{tabular}

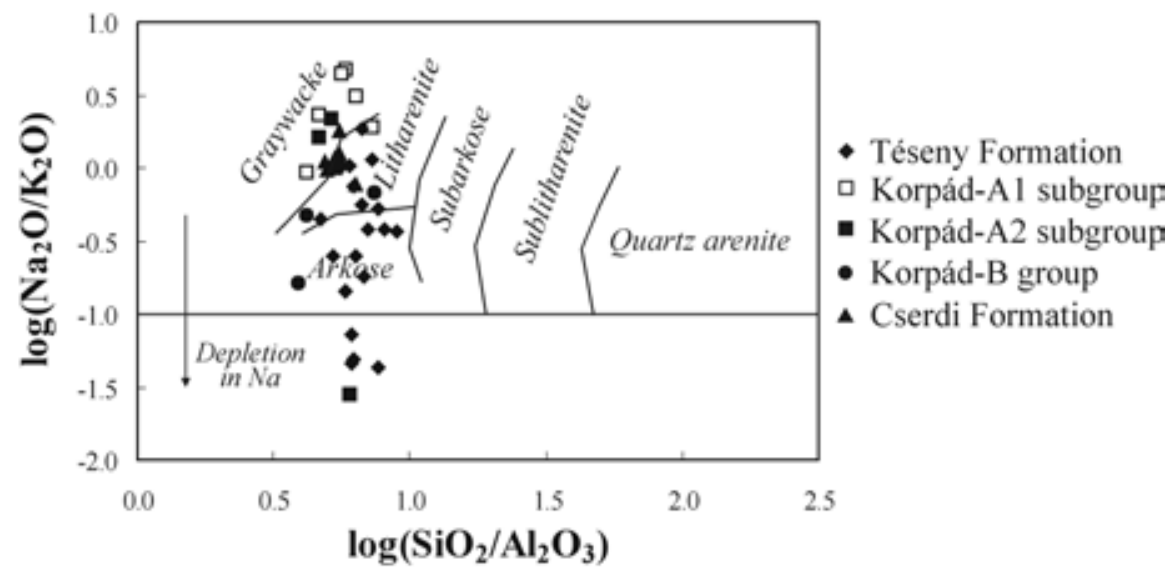

Figure 9. Chemical classification scheme of clastic sediments based on major elements: $\log \left(\mathrm{Na}_{2} \mathrm{O} / \mathrm{K}_{2} \mathrm{O}\right)$ versus $\log \left(\mathrm{SiO}_{2} / \mathrm{Al}_{2} \mathrm{O}_{3}\right)$ diagram after Pettijohn et al. (1972). The symbols are the same as those in Figure 7.

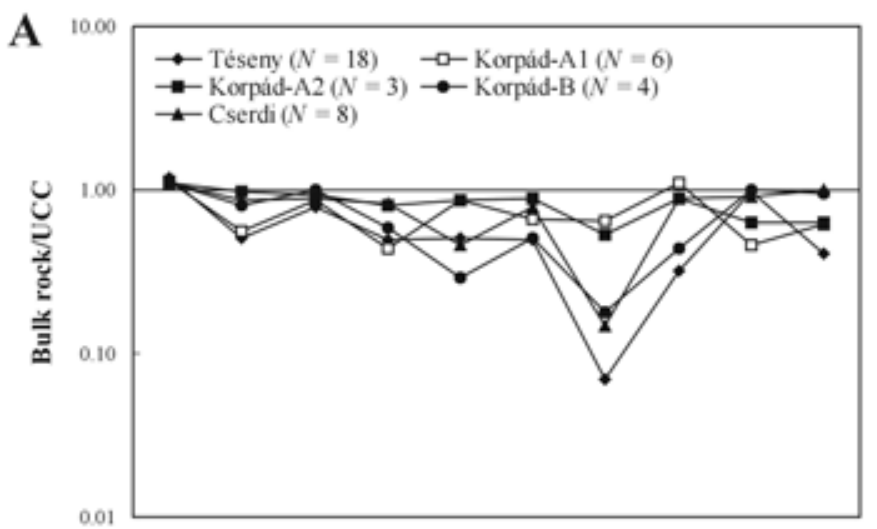

$\mathrm{SiO}_{2} \mathrm{TiO}_{2} \mathrm{Al}_{3} \mathrm{O}, \mathrm{Fe}_{2} \mathrm{O}$, $\mathrm{MnO} \mathrm{MgO} \mathrm{CaO}_{\mathrm{Na}} \mathrm{O} \quad \mathrm{K}_{2} \mathrm{O} \quad \mathrm{P}_{2} \mathrm{O}$,

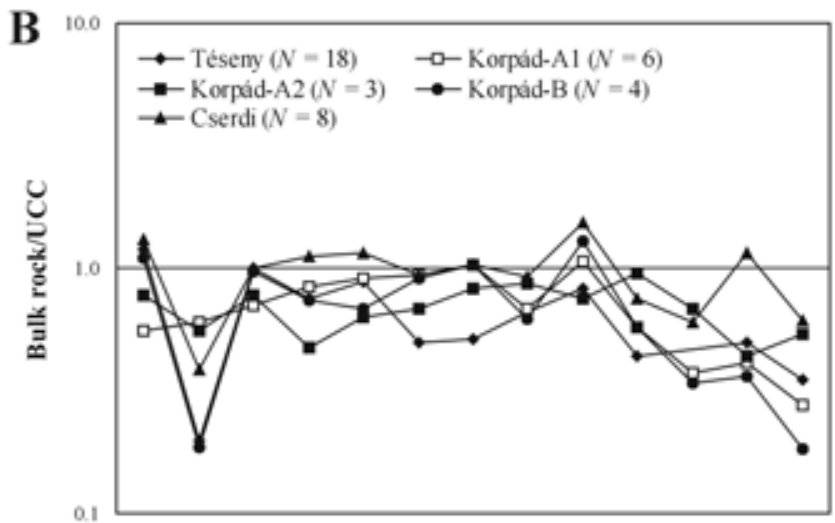

$\begin{array}{lllllllllllll}\mathrm{Rb} & \mathrm{Sr} & \mathrm{Ba} & \mathrm{Th} & \mathrm{U} & \mathrm{Zr} & \mathrm{Hf} & \mathrm{Nb} & \mathrm{Y} & \mathrm{Se} & \mathrm{V} & \mathrm{Cr} & \mathrm{Co}\end{array}$

Figure 10. Upper continental crust (UCC)-normalized (McLennan, 2001) distribution of major (A) and trace (B) elements of southern Transdanubia sandstones. Major element data are recalculated volatile-free. 
$\mathrm{P}_{2} \mathrm{O}_{5}$ relative to the upper continental crust. These differences are probably due to the quartz dilution effect. Low values of $\mathrm{CaO}$ and $\mathrm{Na}_{2} \mathrm{O}$ would also reflect the differential effects of source-area weathering. The Téseny Formation, which shows extremely low $\mathrm{Ca}$ and $\mathrm{Na}$ contents ( 0.29 and $1.24 \mathrm{wt} \%$, respectively) relative to all other rocks, was deposited under humid climatic conditions indicated by the presence of coal seams (Hetényi and RavaszBaranyai, 1976). In addition, it has lower $\mathrm{TiO}_{2}$ and $\mathrm{P}_{2} \mathrm{O}_{5}$ contents relative to the other sedimentation intervals (Fig. 10A), probably because of its lower contents in heavy minerals. However, as has been discussed previously, the Téseny Formation has elevated $\mathrm{SiO}_{2}$ content relative to the other units studied, reflecting the presence of abundant detrital quartz. High median of $\mathrm{SiO}_{2}$ and low $\mathrm{TiO}_{2}$ and $\mathrm{P}_{2} \mathrm{O}_{5}$ values are, therefore, attributed to quartz dilution. On the other hand, the Korpád-A samples (KorpádA1 and Korpád-A2 subgroups) have higher medians of $\mathrm{MnO}$, $\mathrm{CaO}$, and $\mathrm{Na}_{2} \mathrm{O}$, and lower median of $\mathrm{K}_{2} \mathrm{O}$ (Table 3), probably because of their higher contents in carbonate cement and sodic plagioclase, and lower contents in K-bearing mineral phases relative to the other sandstone units.

With respect to the large ion lithophile elements (LILE), the samples are slightly enriched in Rb (except for Korpád-A group), and they are slightly depleted in Ba relative to the upper continental crust (Fig. 10B). In addition, all the units studied show extremely low $\mathrm{Sr}$ abundances (65-210 $\mathrm{ppm}$ ) relative to the upper continental crust (350 ppm). However, the Korpád-A samples are distinctive in terms of lower $\mathrm{Rb}$ and $\mathrm{Ba}$ and higher $\mathrm{Sr}$ abundances compared to the other units (Fig. 10B). This pattern, as with the major elements such as $\mathrm{K}_{2} \mathrm{O}$ and $\mathrm{CaO}$, confirms that the LILE distribution of Korpád-A group reflects its lower contents in Kbearing minerals and higher contents in diagenetic carbonates relative to the other sequences.

In general, the high field strength elements (HFSE) do not display significant lithostratigraphically dependent variations; however, the Téseny Formation has the lowest HFSE contents, and the medians of $Y$ increase from Téseny to Cserdi samples (Table 3). This pattern is similar to the $\mathrm{TiO}_{2}$ data distribution (Fig. 8A), suggesting that their behavior is mainly controlled by the detrital heavy mineral fraction. In the Korpád-A1, Korpád-B, and Cserdi sandstone samples, $\mathrm{Zr}$ and $\mathrm{Hf}$ have normalized values similar to the upper continental crust, whereas $T h$ and $U$ display considerable scatter. These units show minor negative $\mathrm{Nb}$ and positive $\mathrm{Y}$ anomalies (Fig. 8B).

The samples studied are strongly depleted in transition metals, including Sc, V, Cr (except for Cserdi Formation), Ni, and Co with respect to the upper continental crust (Table 3). On the other hand, median of Cr in Cserdi rocks exhibits a minor but significant positive anomaly, indicating a change in the source material (Fig. 10B).

The REE generally show systematic enrichment throughout the sequence, from Pennsylvanian to Upper Permian (Table 4). In a chondrite-normalized (McLennan, 1989) REE diagram (Fig. 11A), the units studied display light REE (LREE) enrichment trends, variable degrees of development of a negative Eu anomaly $\left(\mathrm{Eu} / \mathrm{Eu}^{*}\right)$, and near-flat heavy REE (HREE) patterns. They show strong similarity to the upper continental crust and thus reflect derivation from typical fractionated upper continental crust. The $\mathrm{SiO}_{2}$-rich Téseny Formation has very low total REE ( $2 \mathrm{REE}$ of $60 \mathrm{ppm}$ ), presumably due to quartz dilution (Table 4). Its REE fractionation, expressed by the $\mathrm{La}_{\mathrm{N}} / \mathrm{Yb}_{\mathrm{N}}$ ratio, is higher (10.98) compared with that of the upper continental crust (9.21). The median of $\mathrm{La}_{\mathrm{N}} / \mathrm{Sm}_{\mathrm{N}}$ ratio is 4.23 , which suggests that the LREE fractionation is similar to that of the upper continental crust (4.20). The Korpád samples show quite uniform compositions, with significant LREE enrichment $\left(\mathrm{La}_{N} / \mathrm{Sm}_{\mathrm{N}}\right.$ ratios of 3.164.37) and high $\Sigma \operatorname{REE}(\sim 121 \mathrm{ppm}$ and higher; Table 4). Eu/Eu* stays in a narrow range (0.69-0.75). The Cserdi Formation also has fractionated REE with $\mathrm{La}_{\mathrm{N}} / \mathrm{Yb}_{\mathrm{N}}$ of 7.59 and high $\Sigma \mathrm{REE}$ (156 ppm), but it is slightly enriched in HREE and has a larger

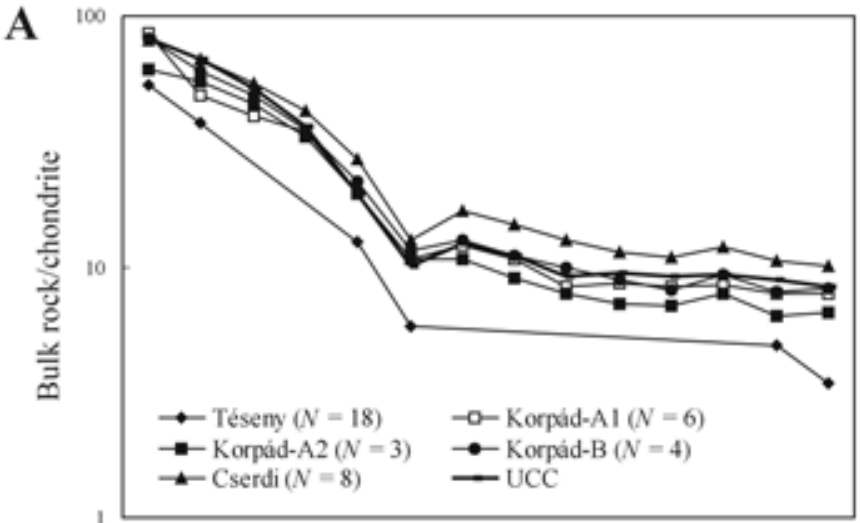

La Ce Pr Nd Sm Eu Gd Tb Dy Ho Er Tm Yb Lu

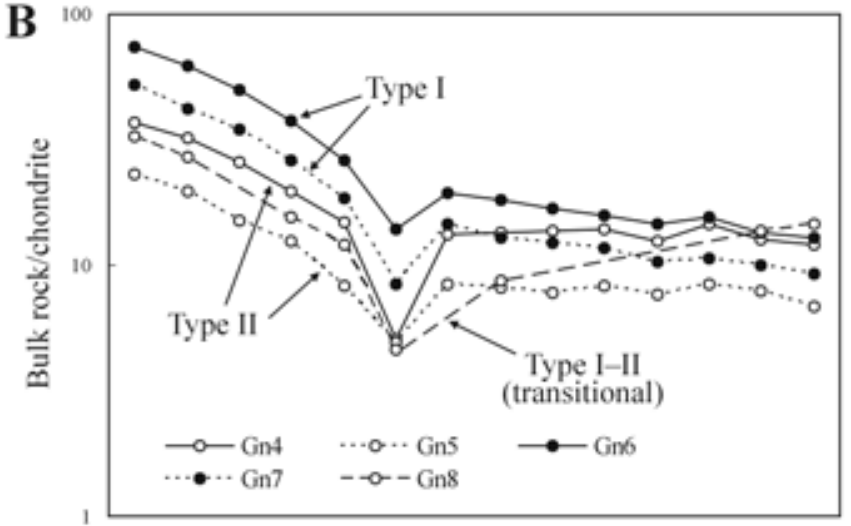

La Ce Pr Nd Sm Eu Gd Tb Dy Ho Er Tm Yb Lu

Figure 11. Chondrite-normalized (McLennan, 1989) rare earth element (REE) patterns of sandstone samples (A) and gneiss clasts from Korpád-B breccia (B). The upper continental crust (McLennan, 2001) pattern is given as a reference. Note fractionated light (L)REE, negative Eu anomaly, and flat heavy $(\mathrm{H}) \mathrm{REE}$ pattern. 
Eu anomaly $\left(\mathrm{Eu} / \mathrm{Eu}^{*}=0.6\right)$ in comparison with the other units and the upper continental crust (Table 4; Fig. 11A).

\section{Geochemistry of Extracted Clasts}

The relic magmatic textures of the Téseny and Korpád-B gneiss clasts discussed already suggest that they can be classified as orthogneiss; therefore, discrimination diagrams for discerning the character of magmatic rocks (Shand, 1943) and the tectonic setting of granites (Pearce et al., 1984) are relevant for determining the geochemical character of their protolith.

The clasts studied have peraluminous character (Fig. 12A). The Téseny and Korpád-B gneiss and Téseny quartz diorite clasts are dissimilar to the main granitoids of the Mórágy Complex (Buda et al., 2000) or Görgeteg-type metamorphites recovered from numerous boreholes in southwestern Transdanubia (Fülöp, 1994). On the other hand, the plotted area of Baksa-type basement rocks from borehole Mgy-1 (Török, 1986; Árgyelán, 2004) is very similar to the area of the Téseny and Korpád-B clasts. The Téseny aplite clast plots in the Mórágy microgranite field (Buda et al., 2000).

It is noteworthy, however, that compositions of the Baksatype metamorphic rocks published by Török (1986) and the samples studied show a linear trend (Fig. 12A), reflecting A/ $\mathrm{CNK}=\mathrm{A} / \mathrm{NK}$ values (where $\mathrm{A} / \mathrm{CNK}=\mathrm{Al}_{2} \mathrm{O}_{3} /\left[\mathrm{CaO}+\mathrm{Na}_{2} \mathrm{O}\right.$ $\left.+\mathrm{K}_{2} \mathrm{O}\right]$ molar; $\mathrm{A} / \mathrm{NK}=\mathrm{Al}_{2} \mathrm{O}_{3} /\left[\mathrm{Na}_{2} \mathrm{O}+\mathrm{K}_{2} \mathrm{O}\right]$ molar). Petrographic features of basement rocks indicate extensive hydrothermal alteration (Török, 1986). In the clasts extracted, strong alteration of feldspars and presence of secondary minerals were observed. Additionally, postdepositional albitization of feldspars cannot be excluded. Therefore, the chemical composition of clasts studied might have a postdepositional origin as well. For these reasons, the mobile $\mathrm{Ca}$ might have been partially removed from these rocks (Fig. 12B), resulting in negligible differences between the $\mathrm{A} / \mathrm{CNK}$ and $\mathrm{A} / \mathrm{NK}$ ratios.

With respect to the alkali elements, both types of clasts $\left(\mathrm{Na}_{2} \mathrm{O} / \mathrm{K}_{2} \mathrm{O}>1\right.$ and $\left.<1\right)$ were recognized (Fig. 12B). Apart from the aplite sample, the Téseny clasts are Na enriched. In addition, type II gneiss clasts from Korpád-B sediments are slightly enriched in $\mathrm{Na}_{2} \mathrm{O}$ relative to $\mathrm{K}_{2} \mathrm{O}$. In contrast, type I gneiss clasts and sample Gn8 with transitional (type I-II) composition are depleted in $\mathrm{Na}_{2} \mathrm{O}$, reflecting their lower sodic plagioclase and higher white mica contents. The Téseny aplite clast also shows $\mathrm{K}$-enrichment; however, it is mineralogically distinct from all other clasts in terms of higher K-feldspar content. Relatively high $\mathrm{Si}_{2} \mathrm{O}$ and $\mathrm{K}_{2} \mathrm{O}$ contents (77.30 and $4.65 \mathrm{wt} \%$, respectively) are characteristic features of this sample, suggesting a high-K character.

Apart from the aplite sample, the Téseny clasts have very low $\Sigma$ REE and low $\mathrm{La}_{\mathrm{N}} / \mathrm{Sm}_{\mathrm{N}}$ ratios (Table 5). The aplite clast is enriched in LREEs and has relatively high values of $\Sigma$ REE, indicating a more differentiated character compare with the gneiss and quartz diorite clasts. The chondrite-normalized REE patterns of Korpád-B gneiss clasts are very similar for both rock types, which have a characteristic negative $\mathrm{Eu}$ anomaly (Fig. 11B). However, type I clasts have higher $\Sigma$ REE values and $\mathrm{La}_{\mathrm{N}} / \mathrm{Yb}_{\mathrm{N}}$ ratios (Table 5), probably because of their higher contents in micas and accessories relative to the type II clasts.

Trace-element analysis after Pearce et al. (1984) indicates that the gneiss and quartz diorite clasts are mainly volcanic arc origin (Fig. 10C); however, they fall very close to the field of within-plate granites. The plotted area of the Korpád-B gneiss clasts is very similar to the area of the Baksa-type metamorphites (Árgyelán, 2004). The composition of the aplite clast plots in the field of syncollisional granites. Its value of $\mathrm{Rb}$ is different from
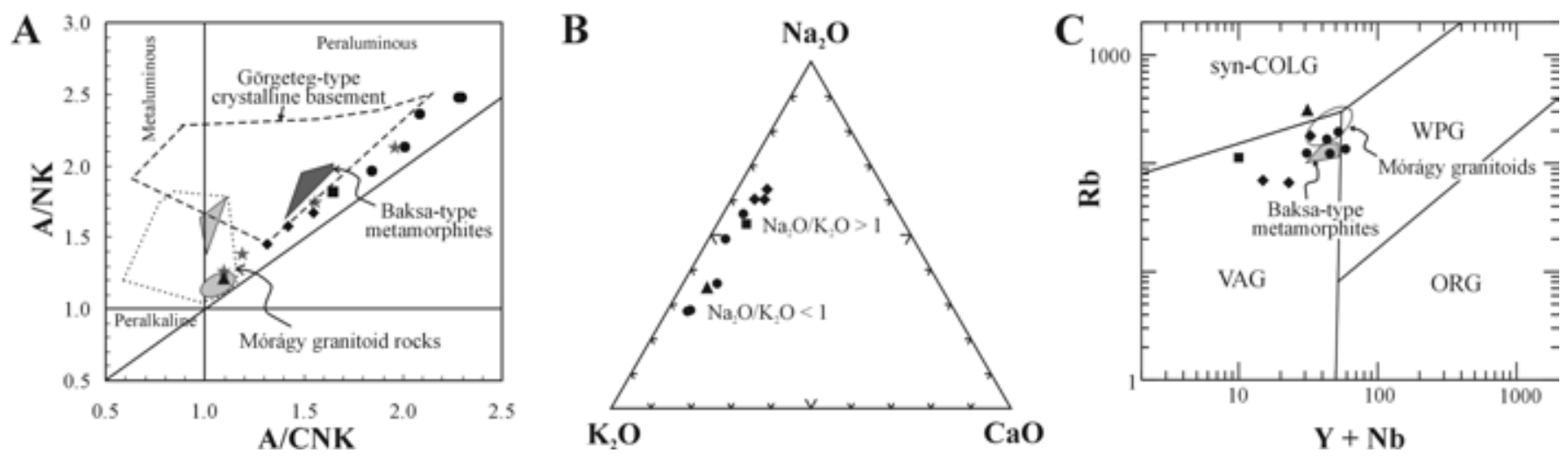

Figure 12. Chemical features of gneiss and granitoid clasts from Téseny and Korpád-B clastics. (A) $\mathrm{Shand}$ 's indices $\left(\mathrm{A} / \mathrm{CNK}_{2}, \mathrm{Al}_{2} \mathrm{O} /[\mathrm{CaO}+\right.$ $\left.\mathrm{Na}_{2} \mathrm{O}+\mathrm{K}_{2} \mathrm{O}\right]$ molar; $\mathrm{A} / \mathrm{NK}, \mathrm{Al}_{2} \mathrm{O}_{3} /\left[\mathrm{Na}_{2} \mathrm{O}+\mathrm{K}_{2} \mathrm{O}\right]$ molar) of clasts. (B) $\mathrm{Na}_{2} \mathrm{O}-\mathrm{K}_{2} \mathrm{O}-\mathrm{CaO}$ ternary diagram. (C) $\mathrm{Rb}$ versus $(\mathrm{Y}+\mathrm{Nb})$ diagram for discerning the tectonic setting of granites (after Pearce et al., 1984), showing the fields of syncollisional granites (syn-COLG), within-plate granites (WPG), volcanic arc granites (VAG), and ocean-ridge granites (ORG). Diamond - Gn1-3; triangle-Apl; square-Qdi; circle-Gn48; star-basement rocks from borehole Mgy-1 after Török (1986); shaded triangle—Mórágy microcline megacryst-bearing granitoids; shaded ellipse-Mórágy microgranite. Fields for Mórágy granitoid data come from Buda et al. (2000). Field for Görgeteg-type crystalline rocks comes from Fülöp (1994). Field for Baksa-type metamorphites from borehole Mgy-1 comes from Árgyelán (2004). 
the other clasts studied, and it is similar to those of the Mórágy granitoid rocks (Buda et al., 2000).

\section{DISCUSSION}

\section{Provenance and Tectonic Setting Based on Sandstone Geochemistry}

Selected immobile trace element (e.g., Th, Zr, Hf, Sc, Co, $\mathrm{Ni}, \mathrm{Cr}$, and REEs) parameters and discriminatory diagrams form a useful tool to characterize the provenance of clastic sedimentary rocks and to decipher the tectonic setting of sandstones (Bhatia, 1985; Bhatia and Crook, 1986; Bauluz et al., 1995; Garver and Scott, 1995; Cullers and Berendsen, 1998). Previous provenance studies (Cullers, 1995; McLennan, 1989; Lee, 2002; Willan, 2003) have shown that Th, Zr, Hf, and REEs are enriched in felsic rather than in mafic rocks because they are highly incompatible during most igneous melting and fractionation processes. On the other hand, input from mafic and ultramafic source areas would result in an enrichment of $\mathrm{Sc}, \mathrm{Co}, \mathrm{Cr}$, and $\mathrm{Ni}$ (Garver and Scott, 1995; Zimmermann and Bahlburg, 2003). These elements are typically much more compatible than REEs, Th, and Zr. Correspondingly, the $\mathrm{Th} / \mathrm{Sc}, \mathrm{La} / \mathrm{Sc}, \mathrm{La} / \mathrm{Co}, \mathrm{Co} / \mathrm{Th}, \mathrm{Cr} / \mathrm{Th}$, and $\mathrm{Cr} / \mathrm{Zr}$ ratios of siliciclastic rocks are very sensitive provenance indicators (Bhatia and Crook, 1986; Bauluz et al., 1995; Cullers and Berendsen, 1998). In addition, anomalously high $\mathrm{Cr}$ and $\mathrm{Ni}$ absolute concentrations with $\mathrm{Cr} / \mathrm{Ni}$ ratios of $\sim 1.2-1.6$ suggest that these elements were derived from a source with ultramafic rocks. Higher $\mathrm{Cr} / \mathrm{Ni}$ ratios are probably indicative of derivation of these elements from mafic volcanic rocks (Garver and Scott, 1995, and references therein).

Additionally, the REE patterns may differ in different sources (Bhatia, 1985; McLennan, 1989; Cullers 1995; Garver and Scott, 1995; Zimmermann and Bahlburg, 2003; Willan, 2003). In general, these studies show that siliciclastic sediment derived from mature continental crust is characterized by LREE enrichment and high $\Sigma$ REE values. On the other hand, sediment derived from young, undifferentiated oceanic arcs has lower $\mathrm{La}_{\mathrm{N}} /$ $\mathrm{Sm}_{\mathrm{N}}$ ratios than either continental arc or old continental crust, has lower $\Sigma$ REE values, and can lack an Eu anomaly.

As discussed in detail in the previous sections, the HFSE and REE contents of the Paleozoic formations analyzed in this study are similar to average upper crustal values. None of these units shows anomalous concentrations of $\mathrm{Sc}, \mathrm{V}, \mathrm{Cr}, \mathrm{Co}$, or $\mathrm{Ni}$, so it is unlikely that much, if any, of the source region was composed of ultramafic rocks. The ubiquitous depletion of compatible elements (Table 3; Fig. 10B) indicates a relatively felsic source area. In addition, the sandstone samples show REE patterns typical of continental-derived sediments, with compositions comparable to the upper continental crust (Fig. 11A).

The key trace element ratios also support a silicic source area (Table 4). All the units studied have high $\mathrm{Th} / \mathrm{Sc}, \mathrm{La} / \mathrm{Sc}$, and $\mathrm{La} / \mathrm{Co}$ ratios, and have higher values than those of the upper continental crust. Moreover, medians of the $\mathrm{Co} / \mathrm{Th}$ ratio are significantly lower in the samples than in the upper continental crust. These parameters are in the range of intermediate to silicic source rocks (Cullers, 1995). The low values of $\mathrm{Cr} / \mathrm{Th}$ and $\mathrm{Cr} / \mathrm{Zr}$ ratios in Téseny and Korpád formations also provide no support for significant amounts of mafic or ultramafic rocks in the source area. $\mathrm{The} \mathrm{Cr} / \mathrm{Th}$ and $\mathrm{Cr} / \mathrm{Zr}$ ratios in the Cserdi Formation, however, may signal a change in sediment provenance. Notably, $\mathrm{Cr}$ and $\mathrm{Ni}$ anomalies do not exist in this unit (Table 3), and the median of $\mathrm{Cr} / \mathrm{Ni}$ ratio is 2.32 , reflecting a volcanic provenance. In the sandstone samples, totally chloritized volcanic glass fragments appear in low proportions, which could be related to a mafic source area. It is not possible, however, that significant amounts of the Cserdi detritus were derived from mafic volcanic rocks. We suspect that these features reflect the higher amounts of mafic minerals, especially biotite and rare pyroxene, derived from felsic volcanites, an interpretation that is supported by high $\Sigma$ REE values, high $\mathrm{La}_{\mathrm{N}} / \mathrm{Sm}_{\mathrm{N}}$ ratio, and sediment composition.

Ternary discrimination diagrams after Bhatia and Crook (1986) have been widely applied to the provenance of sandstones but were developed using small, geographically restricted data sets (Willan, 2003). According to the La-Th-Sc plot (Bhatia and Crook, 1986), the samples studied plot in the fields of continental island arcs and continental margins (Fig. 13). In the Th-Sc$\mathrm{Zr} / 10$ diagram, almost all of the samples plot in the continental island arc and active continental margin fields, whereas in the Th-Co-Zr/10 plot, the majority of the Cserdi samples conform to the continental island arc range, with the Téseny sediments distributed toward the Co apex; the Korpád samples have the strongest passive margin signature (Fig. 13). Consequently, tectonic discrimination diagrams based on these elements and those developed for graywackes of Paleozoic turbidite sequences of eastern Australia (Bhatia and Crook, 1986) are probably not generally applicable to continental sedimentary formations in the Mecsek-Villány area.

The diagrams do, however, display the compositional trends among the samples in this study and confirm that these sediments were dominantly derived from a mixture of various proportions of felsic volcanic rocks, corresponding to the continental island arc field, and granite-gneisses and siliceous volcanics of the uplifted basement, corresponding to the active continental margin field. Additionally, rift-bounded grabens are included in the passive margin-type tectonic setting (Bhatia and Crook, 1986); therefore, the Korpád samples, which were deposited in continental environments of intraplate rift basins (Barabás and Barabás-Stuhl, 1998; Haas et al., 1999), show passive margin affinity.

\section{Source-Area Interpretation}

\section{Téseny Sandstone Formation}

The coal-bearing Pennsylvanian Téseny sediments are interpreted as having formed in a molasse foreland basin proximal to the Variscan fold belt (Hetényi and Ravasz-Baranyai, 1976; Varga et al., 2003). The rock and mineral fragments in the 

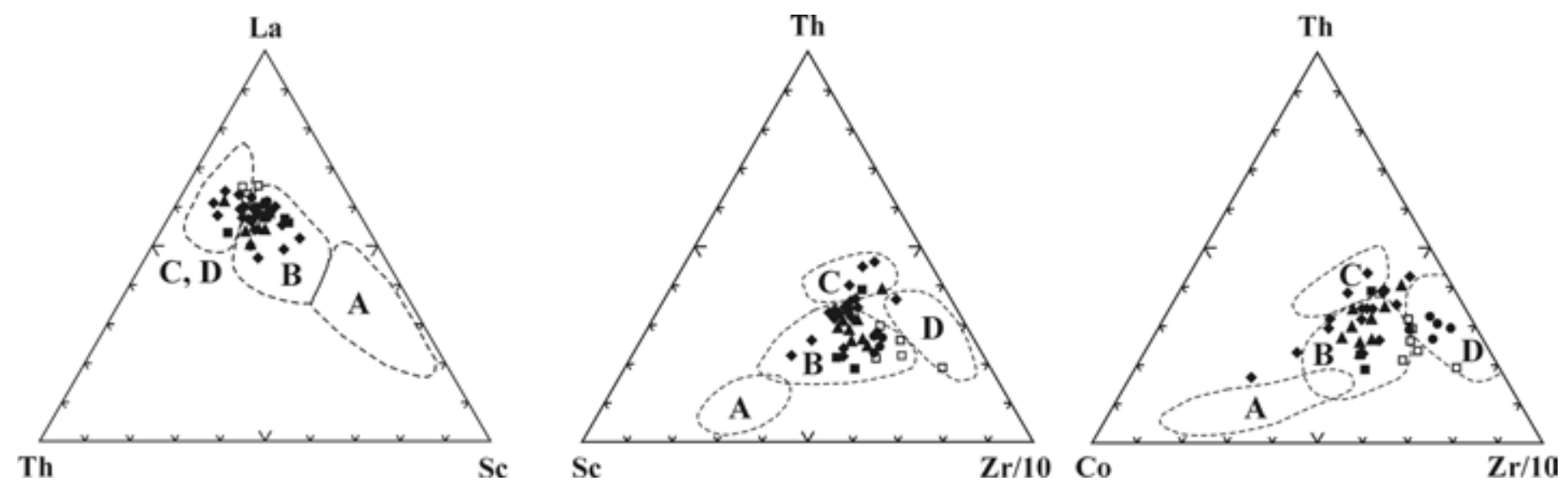

Figure 13. Tectonic setting of the samples studied in $\mathrm{La}-\mathrm{Th}-\mathrm{Sc}, \mathrm{Th}-\mathrm{Sc}-\mathrm{Zr} / 10$, and $\mathrm{Th}-\mathrm{Co}-\mathrm{Zr} / 10$ diagrams after Bhatia and Crook (1986). A — oceanic island arc; B — continental island arc; C—active continental margin; D — passive margin. Symbols are as in Figure 9.

sands and conglomerates are identifiable as coming from three sources: (1) a recycled Variscan orogenic area (collision suture and fold-thrust belt; Varga et al., 2003), indicated by the presence of metamorphic and sedimentary lithic fragments, (2) an uplifted plutonic (granite-gneiss) basement, and (3) an old (probably Variscan) magmatic arc, indicated by the lesser amounts of siliceous volcanic rocks. The local nature of the source areas is manifested by local variations in feldspar, lithic fragment, and clay-mineral contents (Tables 1 and 2). The presence of abundant detrital micas and high proportion of illite \pm muscovite in the clay-mineral assemblage (Fig. 7) confirm the predominance of metamorphic sources for this formation. Chlorite with an Fe(II)rich interlayer, which was detected in the clay-size fraction, is present in minor quantity due to its coarser grain size; essentially, it was formed by alteration of biotite, and less commonly was formed as matrix material.

Our geochemical results also support a silicic source area of the Téseny Formation (Fig. 13). The relatively high median $\mathrm{SiO}_{2}$ value and low HFSE and REE contents in this formation (Figs. 10 and $11 \mathrm{~A}$ ) reflect source rocks more mature in composition than those that supplied detritus to the Permian strata. It is important to note that the relatively quartzose nature of Téseny samples, with extremely low medians of $\mathrm{Na}_{2} \mathrm{O}, \mathrm{CaO}$, and $\mathrm{Sr}$, and high medians of $\mathrm{K}_{2} \mathrm{O}$ and $\mathrm{Rb}$, indicates an intense weathering in the source region, where $\mathrm{Na}, \mathrm{Ca}$, and $\mathrm{Sr}$ are preferentially leached, and $\mathrm{K}$ and $\mathrm{Rb}$ are fixed in clays (Nesbitt et al., 1980). Alternatively, the secondary clay minerals may have been more aluminous, such as kaolinite, and were later enriched in K to form illite (Fedo et al., 1995). The latter scenario is supported by the presence of abundant illitesericite (Fig. 7), both as matrix material between grains and as alteration of weathered feldspar grains, which strongly suggests a potassium metasomatism in the Téseny clastics.

\section{Korpád Sandstone Formation}

As discussed in detail in the previous sections, characteristics of the Lower Permian Korpád Formation vary spatially and are interpreted as local variations in composition of the source areas and diagenetic environments. Relatively immobile trace element relations, however, clearly show that the Korpád Formation, including Korpád-A and Korpád-B groups, was derived from mature upper continental crust (Figs. 11A and 13).

During the Early Permian rifting of the southern margin of the European plate, the Korpád-A group represents the erosion of acidic-intermediate volcanic rocks with variable amounts of metamorphic and coarse crystalline plutonic rocks from the uplifted Variscan basement (Tables 1 and 2; Fig. 13). With regard to the phyllosilicates, the phases present in both Korpád-A1 and KorpádA2 subgroups are illite \pm muscovite and, occasionally, mixed-layer illite-smectite. Kaolinite and chlorite with a Mg-rich interlayer appear only in the Korpád-A1 subgroup (Fig. 7). On the other hand, chlorite with an Fe(II)-rich interlayer occurs in the KorpádA2 subgroup. This might be explained by the possibility that the postdepositional environments of these subgroups were different.

The relationship between the relative abundance of volcanic fragments and chlorite in the $<2 \mu \mathrm{m}$ fraction (Fig. 7) suggests that fine-grained chlorite might have been formed by alteration of volcanic glass. Mg-rich chlorite is a stable phase under evaporitic conditions (Weaver, 1989), which is consistent with the presence of dolomite cement in the Korpád-A1 subgroup. As has been pointed out in the literature, kaolinite disappears from the claymineral parageneses during the burial of the sedimentary series due to such factors as (1) combination with $\mathrm{Mg}$ from destabilized dolomite to produce chlorite; combination with other phases to produce (2) illite and chlorite or (3) mixed-layered minerals (Weaver, 1989; Huang, 1993; Bauluz et al., 1995). In the KorpádA2 subgroup, this third option is supported by the presence of abundant ISII ordered variety of mixed-layer illite-smectite, corresponding to $150-200{ }^{\circ} \mathrm{C}$ burial heating (Weaver, 1989), and $\mathrm{Fe}(\mathrm{II})$-rich chlorite together with dolomite cement.

The provenance of the Korpád-B group represents sources exclusively from uplifted basement rocks (metagranite-gneiss, mica schist). The phyllosilicates present in this group are illite \pm muscovite and kaolinite (Fig. 7) as feldspar alteration products of crystalline sources. 


\section{Cserdi Formation}

The petrographic features and the clay-mineral association (Fig. 7) of the Upper Permian sandstone and conglomerate samples suggest that the Cserdi Formation was derived mainly from acidic volcanic rocks. The presence of minor low-grade to medium-grade metamorphic and plutonic rock fragments indicates additional input from the uplifted Variscan basement. In the clay fraction of the Cserdi Formation, swelling chlorite is a common phase, apparently because of an abundance of volcanic material (Weaver, 1989).

Geochemistry of the Cserdi Formation, especially its high $\mathrm{TiO}_{2}, \mathrm{P}_{2} \mathrm{O}_{5}, \mathrm{Th}, \mathrm{U}, \mathrm{Y}$, and $\mathrm{Cr}$ contents and evolved HREE pattern relative to the other sedimentation intervals (Figs. 10 and 11A), is compatible with textural immaturity and mineralogy of its terrigenous detritus noted previously and may reflect relatively proximal derivation from a felsic volcanic source (Fig. 13). Tourmaline, rutile, zircon, apatite, and monazite occur as dominant accessory phases in this formation. Titanium and $\mathrm{P}$ are networkforming cations in rutile and phosphorus minerals (e.g., apatite and monazite), respectively. The major trace element substitutions occurring in zircon include $\mathrm{Hf}^{4+}, \mathrm{U}^{4+}$, and $\mathrm{Th}^{4+}$ substituting directly for $\mathrm{Zr}^{4+}$. Yttrium and the HREEs can enter the zircon lattice through a coupled substitution scheme involving P and Si (McLennan, 1989; Floyd et al., 1991; Preston et al., 1998). Yttrium and REEs are also commonly present in apatite, substituting directly for $\mathrm{Ca}$. Additionally, the LREEs, Y, and Th are major network-forming cations in monazite (McLennan, 1989; Preston et al., 1998). It is possible, that the whole-rock $\mathrm{TiO}_{2}, \mathrm{P}_{2} \mathrm{O}_{5}, \mathrm{Th}, \mathrm{U}$, Y, and HREE budgets are controlled by the abundances and compositions of the heavy minerals. On the other hand, elevated $\mathrm{Cr}$ content of the Cserdi samples could be related to the totally chloritized (probably mafic) volcanic glass fragments. Another source for $\mathrm{Cr}$ content in these rocks could be the higher amounts of mafic minerals (e.g., biotite and pyroxene) derived from felsic volcanites.

\section{Source-Area Location}

There are relatively well-known metamorphic terrains in the Tisza mega-unit, but their detailed description, including wholerock chemistry, is still missing. Furthermore, the metamorphic and coarse crystalline basement rocks were subsequently strained (mylonitization, cataclasis, etc.) and affected by hydrothermal alteration (Török, 1986; Buda et al., 2000; Szederkényi, 2001), so deciphering original relationships among the basement terrains and overlying siliciclastic units has been difficult.

Based on clast composition, low-grade to medium-grade metamorphic source components might be derived from local sources in the Slavonia-Drava terrane, which consists mostly of gneiss, mica schist, and migmatite (Szederkényi, 2001). Within it, the Baksa subunit is the likely main source area for gneiss/ metagranitoid and mica schist clasts from Téseny and KorpádB sediments (Fig. 12). Unfortunately, however, with our present data set, there is no way to determine the source of Korpád-A and Cserdi metamorphic clasts.
Crystalline plutonic rocks of Mississippian age (340$350 \mathrm{Ma}$ ) are well represented in the Mórágy Complex (Kunság unit) and show great similarities to granitoids of the European Variscides, especially to the Moldanubian zone of the Bohemian Massif (Buda et al., 2000). Variscan quartz monzonite, monzogranite, microgranite, and pegmatite are the main bedrock lithologies in the Mórágy Complex. Outcrops are located in the eastern part of the Mecsek Mountains (Mórágy Hills) and in the westernmost part of the area studied (Fig. 2). This latter area, near the boreholes D 9015 and No. XV, represents the principal coarse crystalline plutonic source that fed the Permian rift basins during deposition of Korpád-A and Cserdi units. Additionally, the inferred sources of fine-grained plutonic rocks (Téseny aplite clasts) are microgranite dikes of the Mórágy Complex (Fig. 12). However, the location of parent rocks of Téseny quartz diorite clasts is unknown. Nonetheless, important information about the provenance of Korpád-A and Cserdi clasts will result from future geochemical and correlation studies aimed at determining the similarities or differences among these units and deduced parent rocks.

Unfortunately, there is no evidence for volcanites older than Early Permian in the Mecsek-Villány area. Therefore, the origin of the acidic-intermediate volcanic source component of the Pennsylvanian Téseny sediments and the lowermost Permian Korpád-A unit is obscure. However, Varga et al. (2003) showed that the characteristics of rhyolite, dacite, trachyandesite, and andesite clasts collected from the Téseny conglomerate reflect convergent, active continental margin affinity. Their features are very similar to those of the Lower to Upper Mississippian to Pennsylvanian calc-alkaline volcanites from the intra-Sudetic Basin, SW Poland (Awdankiewicz, 1999). On the other hand, the petrographic nature of felsic volcanic fragments from the Cserdi unit suggests a provenance from Early Permian rhyolite (Gyürüfü Rhyolite Formation) located in the western part of the Mecsek Mountains (Fig. 3) and associated felsic dikes present within some basements (Fülöp, 1994; Barabás and Barabás-Stuhl, 1998). Future geochemical work on the Cserdi volcanic clasts will provide an important test of this hypothesis.

\section{CONCLUSIONS}

There are distinct contrasts in provenance and source among the late Paleozoic siliciclastic formations analyzed in this study.

The Pennsylvanian Téseny Formation consists of relatively metamorphic lithic-rich sandstones with a combined recycledorogen, basement-uplift, and volcanic-arc provenance. Lowgrade to medium-grade metamorphic source components might be derived from local sources in the Baksa subunit. The inferred sources of fine-grained plutonic rocks are microgranite dikes of the Mórágy Complex (Kunság unit). The high median $\mathrm{SiO}_{2}$ values and low $\mathrm{Na}_{2} \mathrm{O}, \mathrm{CaO}, \mathrm{Sr}, \mathrm{HFSE}$, and REE contents in this formation reflect that source rocks were more mature than those that supplied detritus to the Permian strata. Our data also indicate a more intense weathering in the source region. Additionally, 
Varga et al.

high medians values of $\mathrm{K}_{2} \mathrm{O}$ and $\mathrm{Rb}$, together with the presence of abundant illite-sericite, suggests a potassium metasomatism in the Téseny clastics.

Characteristics of the Lower Permian Korpád Formation vary spatially and are interpreted as local variations in composition of the source areas and diagenetic conditions. Relatively immobile trace element relations, however, clearly show that this formation was mainly derived from mature upper continental crust. The Korpád-A group represents combined acidic-intermediate volcanic and basement-uplift provenances. A possible source for this group is the Mississippian granitoid basement in the western Mecsek Mountains. On the other hand, the provenance of the Korpád-B group represents sources exclusively from the uplifted Baksa-type metamorphic rocks.

The petrographic, clay-mineralogical, and geochemical features of the Upper Permian Cserdi Formation, especially the presence of abundant acidic volcanic fragment and chlorite, together with the high $\mathrm{TiO}_{2}, \mathrm{Th}, \mathrm{U}, \mathrm{Y}$, and $\mathrm{Cr}$ contents, and evolved HREE pattern relative to the underlying formations, may reflect relatively proximal derivation from a felsic volcanic source. It may be possible to link huge amounts of felsic detritus in Cserdi sediments to the Gyürüfü Rhyolite Formation.

These upward variations to less mature deposits might be related to such factors as increasing aridity and favorable conditions for weathering-limited erosion in the source regions and the increase of tectonic activity, including intense acidic volcanism during the Early Permian rifting in the southern margin of the European plate.

\section{APPENDIX}

\section{Description of XRD Methods}

The mineralogical analyses of the whole-rock samples and their clay-size fraction were performed at the Department of Earth and Environmental Sciences of University of Veszprém (Hungary) by X-ray diffraction (XRD), using a Philips PW 1710 diffractometer, $\mathrm{Cu}-\mathrm{K}_{\alpha}$ radiation, and diffracted-beam graphite single-crystal monochromator.

Rock samples were disaggregated under standard conditions using a jaw crusher. Random powder of the bulk sample was used for characterization of the whole-rock mineralogy. Prior to clay fraction $(<2 \mu \mathrm{m})$ separation, the samples were treated to remove the easily soluble carbonates by using $10 \%$ acetic acid and properly dispersed by using ultrasonic deflocculation. The clay fraction was separated from the stabilized aqueous suspension, and oriented specimens were prepared by smearing a paste of $<2$ $\mu \mathrm{m}$ fraction onto a glass slide to minimize size fractionation of the clay particles. The semiquantitative mineralogical analysis of the oriented clay-size fraction was made after air drying at room temperature and analyzed again after keeping the samples under ethylene-glycol-solvated conditions for $4 \mathrm{~h}$ at $80^{\circ} \mathrm{C}$. Analytical procedure was based on methods developed by Kübler (1968) and Árkai (1991). The clay minerals were identified from their characteristic basal reflections (Weaver, 1989). Smectite content of mixed-layer illite-smectite was estimated by the method of Watanabe (1981). Samples containing nonexpanding $14 \AA$ phases were heated at $350,450,550$, and $640{ }^{\circ} \mathrm{C}$ under atmospheric pressure to determine the dominant interlayer cations (Bailey, 1988). After the heat-treatment, specimens were stored in an exsiccator. Semiquantitative estimations of the relative concentrations of the clay minerals were based on the peak area method (Biscaye, 1965) using the intensity factors of Rischák and Viczián (1974) and Árkai (1991). The relative abundance of phyllosilicates was determined by the peak area ratio of the 001/001 reflection of mixed-layer illite-smectite and the 001 reflection of illite, chlorite, and kaolinite after glycolation. Mixedlayer phases close to pure illite were corrected by multiplying by a factor 2, while those close to smectite were multiplied by a factor 0.5. Peak area of discrete illite was corrected in a similar manner by a factor 2 . Kaolinite and chlorite had factor 1 .

\section{Description of XRF Methods}

Major and selected trace element analyses were performed at the Department of Geochemistry of the University of Tübingen (Germany).

$\mathrm{SiO}_{2}(240 \mathrm{ppm}), \mathrm{TiO}_{2}(12 \mathrm{ppm}), \mathrm{Al}_{2} \mathrm{O}_{3}(244 \mathrm{ppm}), \mathrm{Fe}_{2} \mathrm{O}_{3}$ (180 ppm), $\mathrm{MnO}(5 \mathrm{ppm}), \mathrm{MgO}(88 \mathrm{ppm}), \mathrm{CaO}$ (48 ppm), $\mathrm{Na}_{2} \mathrm{O}$ (75 ppm), $\mathrm{K}_{2} \mathrm{O}$ (24 ppm), $\mathrm{P}_{2} \mathrm{O}_{5}(14 \mathrm{ppm}), \mathrm{Rb}(2.9 \mathrm{ppm})$, $\mathrm{Sr}$ (3.0 ppm), Ba (11.1 ppm), Pb (10.3 ppm), Y (1.8 ppm), $\mathrm{V}(2.6 \mathrm{ppm}), \mathrm{Ni}(3.3 \mathrm{ppm}), \mathrm{Zn}$ (3.0 ppm), and Co (1.6 ppm) abundances were established by X-ray fluorescence (XRF) analysis of glass fusion disks and pressed powder pellets using a Bruker AXS S4 Pioneer instrument with a rhodium X-ray source (detection limits are given in parentheses). Samples (1.5000 g) were mixed with $7.5000 \mathrm{~g}$ of Spectromelt Fluxing agent (Merck A12, dilithium tetraborate/lithium metaborate [66:34]) and melted, using the OxiFlux-System of the Firm CBR Analyze Service at $1200{ }^{\circ} \mathrm{C}$ to obtain homogeneous tablets (H. Taubald and F. Pintér, 2004, personal commun.). Results were evaluated with the computer program Traces, which uses 32 standards for calibration. Total $\mathrm{Fe}$ content is reported as $\mathrm{Fe}_{2} \mathrm{O}_{3}$. Loss on ignition (LOI) was determined after heating powdered samples at $1000{ }^{\circ} \mathrm{C}$ for $1 \mathrm{~h}$.

\section{ACKNOWLEDGMENTS}

The Mecsek Ore Environment Company (Pécs, Hungary) made the core samples from different boreholes available for study. The authors are grateful to G. Hámos, L. Merényi, H. Taubald, and F. Pintér for their constructive help in field and laboratory work. Funding for this work came from several sources, including the Hungarian Scientific Research Fund (OTKA) projects T 022938 and T 034924 to György Szakmány, the International Association of Sedimentologists grant 2003 to Andrea Varga, and the Pro Renovanda Cultrura Hungariae (PRCH) Student Science Foundation. This study also forms part of Andrea 
Complex examination of Upper Paleozoic siliciclastic rocks

Varga's Ph.D. research at Eötvös University (Budapest, Hungary). Thoughtful reviews by W.A. Heins and G. Yaxley contributed significant improvement to the manuscript.

\section{REFERENCES CITED}

Árgyelán, T., 2004, A Korpádi Homokkő Formáció kavicsanyagának kőzettani és geokémiai vizsgálata a Máriagyúd-1 számú fúrásban [Petrology and geochemistry of metamorphic clasts of the Lower Permian conglomerate unit from borehole Máriagyüd-1] [National Scientific Conference of Students thesis]: Budapest, Eötvös University, 73 p.

Árgyelán, T., 2005, A XV. szerkezeti fúrás által feltárt Cserdi Konglomerátum formáció gneisz és granitoid kavicsanyagának kőzettani és geokémiai vizsgálata [Petrology and geochemistry of gneiss and granitoid clasts of Cserdi Conglomerate Formation from borehole No. XV] [M.S. thesis]: Budapest, Eötvös University, 117 p.

Árkai, P., 1991, Chlorite crystallinity: An empirical approach with illite crystallinity, coal rank and mineral facies as exemplified by Palaeozoic and Mesozoic rocks of northeast Hungary: Journal of Metamorphic Geology, v. 9, p. $723-734$

Arribas, J., Alonso, Á., Mas, R., Tortosa, A., Rodas, M., Barrenechea, J.F., Alonso-Azcárate, J., and Artigas, R., 2003, Sandstone petrography of continental depositional sequences of an intraplate rift basin: Western Cameros Basin (north Spain): Journal of Sedimentary Research, v. 73, p. 309-327.

Awdankiewicz, M., 1999, Volcanism in a late Variscan intramontane trough: The petrology and geochemistry of the Carboniferous and Permian volcanic rocks of the intra-Sudetic Basin: SW Poland: Geologica Sudetica, v. 32 , p. $83-111$

Bailey, S.W., 1988, Chlorites: Structures and crystal chemistry, in Bailey, S.W., ed., Hydrous Phyllosilicates (Exclusive of Micas): Reviews in Mineralogy, v. 19 , p. $347-403$

Balogh, K., and Barabás, A., 1972, The Carboniferous and Permian of Hungary: Acta Mineralogica-Petrographica, Szeged, v. 20, no. 2, p. 191-207.

Barabás, A., and Barabás-Stuhl, A., 1998, A Mecsek és környezete perm képződményeinek rétegtana [Stratigraphy of the Permian formations in the Mecsek Mountains and its surroundings], in Bérczi, I., et al., eds., Magyarország Geológiai Képződményeinek Rétegtana [Stratigraphy of Geological Formations of Hungary]: Budapest, MOL Hungarian Oil and Gas Company and Geological Institute of Hungary, p. 187-215.

Bauluz, B., Mayayo Burillo, M.J., Fernandez-Nieto, C., and Gonzalez Lopez, J.M., 1995, Mineralogy and geochemistry of Devonian detrital rocks from the Iberian Range (Spain): Clay Minerals, v. 30, p. 381-394.

Bhatia, M.R., 1985, Rare earth element geochemistry of Australian Paleozoic graywackes and mudrocks: Provenance and tectonic control: Sedimentary Geology, v. 45, p. 97-113, doi: 10.1016/0037-0738(85)90025-9.

Bhatia, M.R., and Crook, K.A.W., 1986, Trace element characteristics of graywackes and tectonic setting discrimination of sedimentary basins: Contributions to Mineralogy and Petrology, v. 92, p. 181-193, doi: 10.1007/ BF00375292.

Biscaye, P.E., 1965, Mineralogy and sedimentation of recent deep-sea clay in the Atlantic Ocean and adjacent seas and oceans: Geological Society of America Bulletin, v. 76, p. 803-832.

Brügel, A., Dunkl, I., Frisch, W., Kuhlemann, J., and Balogh, K., 2003, Geochemistry and geochronology of gneiss pebbles from foreland molasse conglomerates; geodynamic and paleogeographic implications for the Oligo-Miocene evolution of the eastern Alps: The Journal of Geology, v. 111 , no. 5 , p. $543-563$, doi: $10.1086 / 376765$.

Buda, G., Puskás, Z., Gál-Sólymos, K., Klötzli, U., and Cousens, B.L., 2000, Mineralogical, petrological and geochemical characteristics of crystalline rocks of the Üveghuta boreholes (Mórágy Hills, south Hungary): Budapest, MÁFI Évi Jelentése az 1999 évről [Annual Report of the Geological Institute of Hungary, 1999], p. 231-252.

Cox, R., Lowe, D.R., and Cullers, R.L., 1995, The influence of sediment recycling and basement composition on evolution of mudrock chemistry in the southwestern United States: Geochimica et Cosmochimica Acta, v. 59, no. 14, p. 2919-2940, doi: 10.1016/0016-7037(95)00185-9.

Csontos, L., and Nagymarosy, A., 1998, The Mid-Hungarian line: A zone of repeated tectonic inversions: Tectonophysics, v. 297, p. 51-71, doi: 10.1016/S0040-1951(98)00163-2.
Csontos, L., Nagymarosy, A., Horváth, F., and Kovác, M., 1992, Tertiary evolution of the intra-Carpathian area: A model: Tectonophysics, v. 208, p. 221-241, doi: 10.1016/0040-1951(92)90346-8.

Csontos, L., Benkovics, L., Bergerat, F., Mansy, J., and Wórum, G., 2002, Tertiary deformation history from seismic section study and fault analysis in a former European Tethyan margin (the Mecsek-Villány area, SW Hungary): Tectonophysics, v. 357, p. 81-102, doi: 10.1016/S00401951(02)00363-3.

Cullers, R.L., 1995, The controls on the major- and trace-element evolution of shales, siltstones and sandstones of Ordovician to Tertiary age in the Wet Mountains region, Colorado, U.S.A.: Chemical Geology, v. 123, p. 107131, doi: 10.1016/0009-2541(95)00050-V.

Cullers, R.L., and Berendsen, P., 1998, The provenance and chemical variation of sandstones associated with the Mid-Continent Rift system, USA: European Journal of Mineralogy, v. 10, p. 987-1002.

Fazekas, V., 1987, A mecseki perm és alsótriász korú törmelékes formációk ásványos összetétele (Mineralogical composition of Permian and Lower Triassic clastics from the Mecsek Mts.): Földtani Közlöny (Bulletin of the Hungarian Geological Society), v. 117, no. 1, p. 11-30.

Fedo, C.M., Nesbitt, H.W., and Young, G.M., 1995, Unraveling the effects of potassium metasomatism in sedimentary rocks and paleosols, with implications for paleoweathering conditions and provenance: Geology, v. 23 , p. $921-924$, doi: 10.1130/0091-7613(1995)023<0921: UTEOPM>2.3.CO;2.

Floyd, P.A., Shail, R., Leveridge, B.E., and Franke, W., 1991, Geochemistry and provenance of Rhenohercynian synorogenic sandstones: Implications for tectonic environment discrimination, in Morton, A.C., et al., eds., Developments in Sedimentary Provenance Studies: Geological Society [London] Special Publication 57, p. 173-188.

Folk, R.L., 1968, Petrology of Sedimentary Rocks: Austin, Texas, Hemphill's, $170 \mathrm{p}$.

Fülöp, J., 1994, Magyarország geológiája: Paleozoikum II [Geology of Hungary: Paleozoic, II]: Budapest, Akadémiai Kiadó, 447 p.

Gaillardet, J., Dupré, B., and Allègre, C.J., 1999, Geochemistry of large river suspended sediments: Silicate weathering or recycling tracer: Geochimica et Cosmochimica Acta, v. 63, no. 23-24, p. 4037-4051, doi: 10.1016/ S0016-7037(99)00307-5.

Garver, J.I., and Scott, T.J., 1995, Trace elements in shale as indicators of crustal provenance and terrane accretion in the southern Canadian Cordillera: Geological Society of America Bulletin, v. 107, p. 440-453, doi: 10.1130/0016-7606(1995)107<0440:TEISAI $>2.3 . \mathrm{CO} ; 2$.

Golonka, J., and Ford, D., 2000, Pangean (Late Carboniferous-Middle Jurassic) paleoenvironment and lithofacies: Palaeogeography, Palaeoclimatology, Palaeoecology, v. 161, p. 1-34, doi: 10.1016/S0031-0182(00)00115-2.

Haas, J., Hámor, G., and Korpás, L., 1999, Geological setting and tectonic evolution of Hungary: Geologica Hungarica Series Geologica, v. 24, p. 179-196.

Hetényi, R., and Ravasz-Baranyai, L., 1976, A baranyai antracittelepes felsőkarbon összlet a Siklósbodony 1. és a Bogádmindszent 1. sz. fúrás tükrében [The anthracitiferous Upper Carboniferous sequence of Baranya, South Hungary, in the light of boreholes Siklósbodony-1 and Bogádmindszent-1]: Budapest, MÁFI Évi Jelentése az 1973 évröl [Annual Report of the Geological Institute of Hungary, 1973], p. 323-361.

Huang, W.L., 1993, The formation of illitic clays from kaolinite in KOH solution from $225^{\circ} \mathrm{C}$ to $350^{\circ} \mathrm{C}$ : Clays and Clay Minerals, v. 41, no. 6, p. $645-$ 654, doi: 10.1346/CCMN.1993.0410602.

Jámbor, Á., 1969, Karbon képződmények a Mecsek és a Villányi-hegység közötti területen [Carboniferous deposits in the area between the Mecsek and Villány Mountains]: Budapest, MÁFI Évi Jelentése az 1967 évről [Annual Report of the Geological Institute of Hungary, 1967], p. 215-221.

Kübler, B., 1968, Evaluation quantitative du métamorphisme par la cristallinité de l'illite: Bulletin de Centre Recherche Pau-SNPA, v. 2, p. 385-397.

Lee, Y.I., 2002, Provenance derived from the geochemistry of late Paleozoicearly Mesozoic mudrocks of the Pyeongan Supergroup, Korea: Sedimentary Geology, v. 149, p. 219-235, doi: 10.1016/S0037-0738(01)00174-9.

McLennan, S.M., 1989, Rare earth elements in sedimentary rocks: Influence of provenance and sedimentary processes, in Lipin, B.R., et al., eds., Geochemistry and Mineralogy of Rare Earth Elements: Reviews in Mineralogy, v. 21, p. 169-200.

McLennan, S.M., 2001, Relationships between the trace element composition of sedimentary rocks and upper continental crust: Geochemistry, Geophysics, Geosystems, v. 2, doi: 10.1029/2000GC000109. 
Nagy, E., 1968, A Mecsek hegység triász időszaki képződményei [Triassic formation of the Mecsek Mountains]: MÁFI Évkönyv [Annales of the Geological Institute of Hungary], v. 51, 198 p.

Nesbitt, H.W., Markovics, G., and Price, R.C., 1980, Chemical processes affecting alkalines and alkaline earths during continental weathering: Geochimica et Cosmochimica Acta, v. 44, p. 1659-1666, doi: 10.1016/00167037(80)90218-5.

Noda, A., Takeuchi, M., and Adachi, M., 2004, Provenance of the Murihiku terrane, New Zealand: Evidence from the Jurassic conglomerates and sandstones in Southland: Sedimentary Geology, v. 164, p. 203-222, doi: 10.1016/j.sedgeo.2003.10.003.

Pearce, J., Harris, N.B.W., and Tindle, A.G., 1984, Trace element discrimination diagrams for the interpretation of granitic rocks: Journal of Petrology, v. 25 , p. 956-983.

Pettijohn, F.J., Potter, P.E., and Siever, R., 1972, Sand and Sandstone: New York, Springer-Verlag, $618 \mathrm{p}$.

Preston, J., Hartley, A., Hole, M., Buck, S., Bond, J., Mange, M., and Still, J., 1998, Integrated whole-rock trace element geochemistry and heavy mineral chemistry studies: Aids to the correlation of continental red-bed reservoirs in the Beryl Field: UK North Sea: Petroleum Geoscience, v. 4, p. $7-16$.

Rischák, G., and Viczián, I., 1974, Agyagásványok bázisreflexióinak intenzitását meghatározó ásványtani tényezők [Mineralogical factors determining the intensity of basal reflections of clay minerals]: Budapest, MÁFI Évi Jelentése az 1972 évröl [Annual Report of the Geological Institute of Hungary, 1972], p. 229-256.

Shand, S.J., 1943, Eruptive Rocks: Their Genesis, Composition, Classification and their Relations to Ore-Deposits (second ed.): New York, Wiley, $444 \mathrm{p}$.

Szederkényi, T., 2001, Tisza mega-unit, in Haas, J., ed., Geology of Hungary: Budapest, Eötvös University Press, p. 148-169.

Török, K., 1986, Adatok a Dél-Dunántúl kristályos aljzatának felépítéséhez [Composition of the crystalline basement rocks from southern Transdanubia, Hungary] [M.S. thesis]: Budapest, Eötvös University, 75 p.

Varga, A.R., and Szakmány, Gy., 2004, Geochemistry and provenance of the
Upper Carboniferous sandstones from borehole Diósviszló-3 (Téseny Sandstone Formation, SW Hungary): Acta Mineralogica-Petrographica, Szeged, v. 45, no. 2, p. 7-14.

Varga, A., Szakmány, Gy., Józsa, S., and Máthé, Z., 2001, A nyugat-mecseki alsó-miocén konglomerátum karbon homokkő kavicsainak és a Tésenyi Homokkő Formáció képződményeinek petrográfiai és geokémiai összehasonlítása [Petrographic and geochemical comparison between the Carboniferous sandstone pebbles of the Lower Miocene conglomerate from western Mecsek Mountains and Téseny Sandstone Formation]: Földtan Közlöny [Bulletin of the Hungarian Geological Society], v. 131, p. 11-36.

Varga, A.R., Szakmány, Gy., Józsa, S., and Máthé, Z., 2003, Petrology and geochemistry of Upper Carboniferous siliciclastic rocks (Téseny Sandstone Formation) from the Slavonian-Drava unit (Tisza megaunit, S Hungary)_Summarized results: Acta Geologica Hungarica, v. 46, no. 1, p. $95-113$.

Varga, A.R., Raucsik, B., and Szakmány, Gy., 2004, A Siklósbodony Sb-1 mélyfúrás feltételezett karbon-perm határképződményeinek ásványtani, kőzettani és geokémiai jellemzői [Mineralogical, petrographic and geochemical characteristics of siliciclastic rocks from the supposed Carboniferous-Permian boundary in borehole Siklósbodony Sb-1, southwestern Hungary]: Földtani Közlöny [Bulletin of the Hungarian Geological Society], v. 134, no. 3, p. 321-343.

Watanabe, T., 1981, Identification of illite/montmorillonite interstratifications by X-ray powder diffraction: Journal of Mineralogical Society of Japan, v. 15 , Special Issue, p. 32-41.

Weaver, C.E., 1989, Clays, Muds, and Shales: Amsterdam, Elsevier, 819 p.

Willan, R.C.R., 2003, Provenance of Triassic-Cretaceous sandstones in the Antarctic Peninsula: Implications for terrane models during Gondwana breakup: Journal of Sedimentary Research, v. 73, no. 6, p. 1062-1077.

Zimmermann, U., and Bahlburg, H., 2003, Provenance analysis and tectonic setting of the Ordovician clastic deposits in the southern Puna Basin, NW Argentina: Sedimentology, v. 50, no. 6, p. 1079-1104, doi: 10.1046 j.1365-3091.2003.00595.x.

Manuscript ACCePted By the Society 9 August 2006 